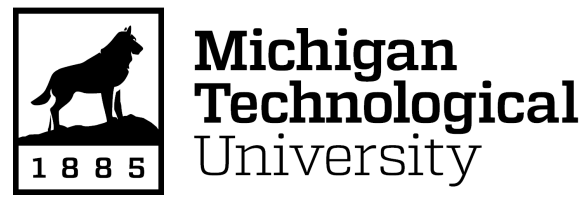

Michigan Technological University Digital Commons @ Michigan Tech

Dissertations, Master's Theses and Master's Reports

2021

UNDERSTORY DYNAMICS ACROSS 62-YEARS OF A NORTHERN HARDWOOD MANAGEMENT GRADIENT STUDY

Heidi Harmala

Michigan Technological University, heharmal@mtu.edu

Copyright 2021 Heidi Harmala

Recommended Citation

Harmala, Heidi, "UNDERSTORY DYNAMICS ACROSS 62-YEARS OF A NORTHERN HARDWOOD

MANAGEMENT GRADIENT STUDY", Open Access Master's Thesis, Michigan Technological University, 2021.

https://doi.org/10.37099/mtu.dc.etdr/1236

Follow this and additional works at: https://digitalcommons.mtu.edu/etdr

Cart of the Forest Management Commons 


\title{
UNDERSTORY DYNAMICS ACROSS 62-YEARS OF A NORTHERN HARDWOOD MANAGEMENT GRADIENT STUDY
}

\author{
By \\ Heidi E. Harmala \\ A THESIS \\ Submitted in partial fulfillment of the requirements for the degree of \\ MASTER OF SCIENCE \\ In Forestry
}

MICHIGAN TECHNOLOGICAL UNIVERSITY

2021

(C) 2021 Heidi E. Harmala 
This thesis has been approved in partial fulfillment of the requirements for the Degree of MASTER OF SCIENCE in Forestry.

College of Forest Resources and Environmental Science

Thesis Co-Advisor: Dr. Robert Froese

Thesis Co-Advisor: $\quad$ Dr. Blair Orr

Committee Member: Dr. Christel Kern

College Dean: Dr. Andrew Storer 


\section{Table of Contents}

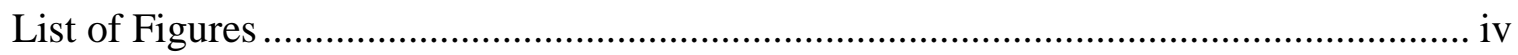

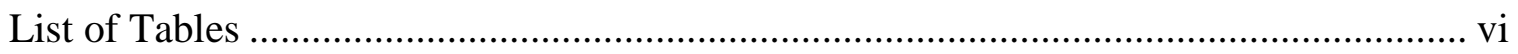

Acknowledgements ............................................................................................ vii

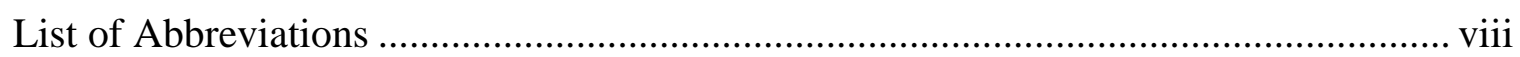

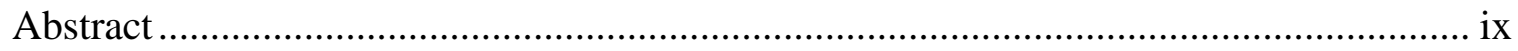

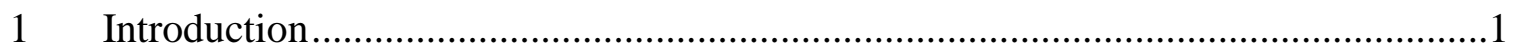

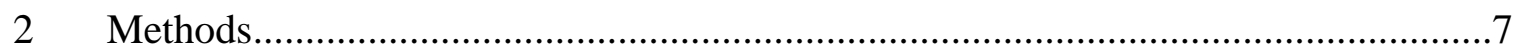

2.1 Site Description and Study Area ……………….....................................

2.2 The Cutting Methods Study .....................................................................

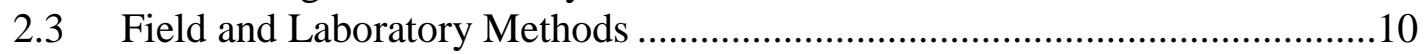

2.3.1 Structure and Composition ............................................................10

2.3.2 Sugar Maple Age Structure.............................................................12

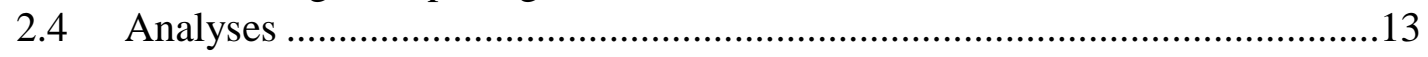

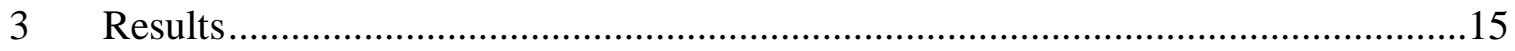

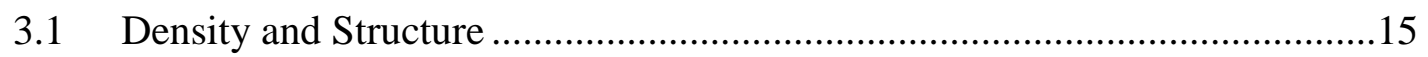

3.1.1 Small Seedlings $(<1 \mathrm{ft}$ tall $)$..........................................................15

3.1.2 Large Seedlings ( $1-3 \mathrm{ft}$ tall, $>3 \mathrm{ft}$ and $<1 \mathrm{in} \mathrm{dbh})$.........................16

3.1.3 Saplings (1-3 in dbh, 3-5 in dbh) ..............................................16

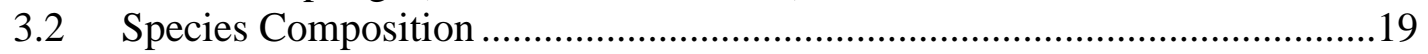

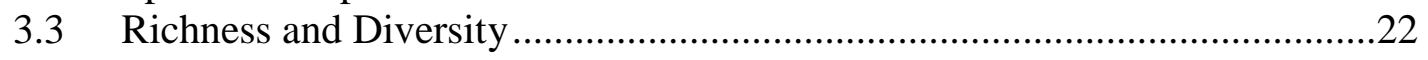

3.4 Recruitment and Age ...........................................................................28

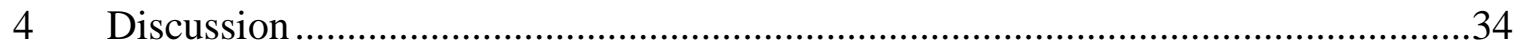

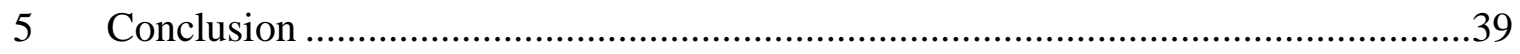

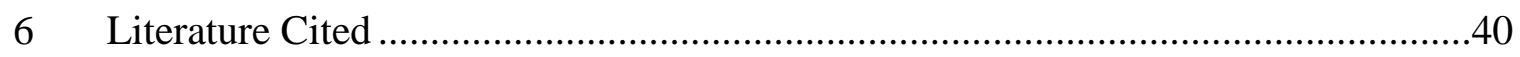

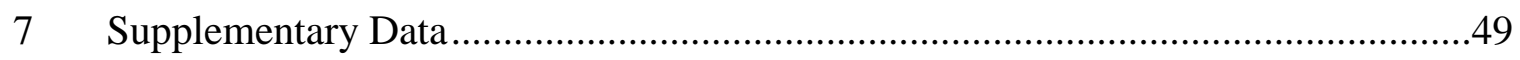




\section{List of Figures}

Figure 3-1 Relationship between pre-harvest basal area $\left(\mathrm{ft}^{2} \mathrm{ac}^{-1}\right)$ of trees larger than 12 inch dbh and the frequency (stems $\mathrm{ac}^{-1}$ ) of five regeneration size classes: S.Seed ( $<1 \mathrm{ft}$ tall), M .Seed (1-3 ft tall), L.Seed ( $>3 \mathrm{ft}$ tall and $<1$ in dbh), S.Sap (1-3 in dbh), L.Sap (3-5 in dbh) across three 10-year harvest cycles, data collected: (a) 1998, (b) 2008, (c) 2020. Each data point within one color represents one of the regularly cut treatments (does not include the DL 5).

Figure 3-2 Species distribution besides sugar maple in three size classes before the 1998 harvest entry. Small seedlings are $<1 \mathrm{ft}$ tall, large seedlings are $>1 \mathrm{ft}$ tall and $<1$ in $\mathrm{dbh}$, and saplings are between 1-5 in dbh. Values on the top of the bars indicate total percent sugar maple.

Figure 3-3 Species distribution besides sugar maple in three size classes before the 2008 harvest entry. Small seedlings are $<1 \mathrm{ft}$ tall, large seedlings are $>1 \mathrm{ft}$ tall and $<1$ in $\mathrm{dbh}$, and saplings are between 1-5 in dbh. Values on the top of the bars indicate total percent sugar maple.

Figure 3-4 Species distribution besides sugar maple in three size classes after the 2018 harvest entry. Small seedlings are $<1 \mathrm{ft}$ tall, large seedlings are $>1 \mathrm{ft}$ tall and $<1$ in dbh, and saplings are between 1-5 in dbh. Values on the top of the bars indicate total percent sugar maple.

Figure 3-5 Difference between the proportion of sugar maple in the overstory $(\geq 5$ in $\mathrm{dbh}$ ) and proportion in the understory ( $<5$ in $\mathrm{dbh})$, at the study establishment (1957) as well as the 1998, and 2018 harvest cycles. Positive values indicate greater proportional abundance in the overstory when compared to the understory.

Figure 3-6 Frequency of stems ac-1 in three seedling size classes ( $<1 \mathrm{ft}$ tall; $1-3$ ' tall; 3'+ tall and $<1$ " dbh) and two sapling size classes (1-3" dbh; 3-5" dbh) by treatment, for harvests in 1998, 2008, and 2018.

Figure 3-7 Average frequency of stems ac-1 across 1998, 2008, and 2018 harvest entry in three seedling size classes ( $<1 \mathrm{ft}$ tall; $1-3$ ' tall; 3' + tall and $<1$ ' $\mathrm{dbh}$ ) and two sapling size classes (1-3" dbh; 3-5" dbh) by treatment.

Figure 3-8 Relationship between breast height annual ring count (years) and diameter at breast height (in) for sugar maple regeneration $(\mathrm{n}=50)>1 \mathrm{ft}$ tall and $<5$ in $\mathrm{dbh}$ by treatment. Grey rectangle indicates the upper limit of sampling, and the establishment year (1957) of the study.

Figure 3-9 Relationship between stump height annual ring count (years) and diameter at stump height (in) for sugar maple regeneration $(\mathrm{n}=55)>1 \mathrm{ft}$ tall and $<5$ in $\mathrm{dbh}$ by treatment. Grey rectangle indicates the upper limit of sampling, and the establishment year (1957) of the study.

Figure 3-10 Boxplots of years to breast height for sugar maple regeneration by treatment. Solid grey dot indicates mean. 
Figure 7-1 Diagram of Cutting Methods Study, Alberta, Michigan. Adapted from (Bourdo 1957).......................................................................................49

Figure 7-2 Diagram of sample design for regeneration plots within 1/10-acre subplots. Digitized and adapted from Bodine (2000). Plot radius of $1 / 50$-acre is 16.7 feet and radius of $1 / 1000$-acre is 3.7 feet. 


\section{List of Tables}

Table 3-1 Understory density, richness (S), and Shannon-Wiener's Diversity Index ( $\left.\mathrm{H}^{\prime}\right)$ pre-harvest (2008) and post-harvest (2018) by treatment. Means and one standard deviation (italicized). Small seedlings $<1 \mathrm{ft}$ tall, large seedlings are $>1 \mathrm{ft}$ tall and

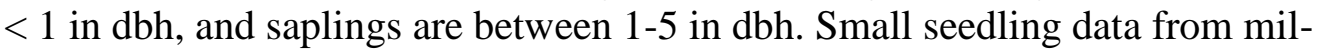
acre plots $(n=30$ per treatment) large seedling and sapling data from one-fiftieth acre plots ( $\mathrm{n}=10$ per treatment).

Table 3-2 Regeneration densities by treatment and size class for (a) 1998, (b) 2008, and

(c) 2018 harvest cycles.

Table 3-3 Summary table for breast height diameter-age regression and years to breast height boxplots for sugar maple regeneration by treatment.

Table 7-1 Pre- and post-harvest basal area $\left(\mathrm{ft}^{2} \mathrm{ac}^{-1}\right)$ and harvested proportion for 1998, 2008, and 2018 harvest entries.

Table 7-2 Pre-harvest basal area $\left(\mathrm{ft}^{2} \mathrm{ac}^{-1}\right)$ of live trees $>12$ in $\mathrm{dbh}$ for the 1998, 2008, and 2018 harvest entries. These data accompany those presented in Figure 3-1.

Table 7-3 Regression equations and coefficients of determination for the relationship between pre-harvest basal area in trees greater than 12 in dbh and regeneration densities across all treatments in each size class for the past three harvest entries.

Table 7-4 Regeneration densities (stems ac ${ }^{-1}$ ) by size class and species prior to the 1998 harvest. Data reproduced from Bodine (2000).

Table 7-5 Regeneration densities ( $\left(\mathrm{stems} \mathrm{ac}^{-1}\right.$ ) by size class and species prior to the 2008 harvest.

Table 7-6 Regeneration densities (stems ac ${ }^{-1}$ ) by size class and species after the 2018 harvest.

Table 7-7 Summary information for treatments in the Cutting Methods Study, Alberta, Michigan. Information adapted from Draper (2021).... 


\section{Acknowledgements}

The completion of my thesis and graduate degree could not have been possible if not for the encouragement and support of several people and organizations.

I extend my sincere thanks to Robert Froese who provided me this opportunity, and despite the many changes, advised and guided my often-rambling thoughts through the past two years. Without his help, I would not have gained the confidence to call myself a writer and researcher. I also would like to thank my committee members, Christel Kern and Blair Orr, for their valuable input and feedback.

Thanks to the College of Forest Resources and Environmental Science and the Ecosystem Science Center for the financial support through the teaching assistantship and research grant.

Many thanks my fellow graduate students who brought humor and coffee to the office. Special thanks to Maeve and Ian who spent countless hours assisting in the fieldwork.

To the 75 students of the past two Fall Camps, your enthusiasm and humor made the days more enjoyable.

Lastly, to my friends and family, thank you for listening to my woes, patiently adjusting with my working hours, and giving me numerous words of encouragement when I got stuck in the rut. 


\section{List of Abbreviations}

STS: single-tree selection

DL: diameter-limit

AE: American elm (Ulmus americana Linnaeus)

BC: black cherry (Prunus serotina Ehrhart)

BW: American basswood (Tilia americana Linnaeus)

EH: Eastern hemlock (Tsuga canadensis (Linnaeus) Carrière)

HH: Eastern hophornbeam (Ostrya virginiana (Miller) K. Koch)

RM: red maple (Acer rubrum Linnaeus)

RO: Northern red oak (Quercus rubra Linnaeus)

DW: alternate-leaf dogwood (Cornus alternifolia Linnaeus f.)

YB: yellow birch (Betula alleghaniensis Britton)

WS: white spruce (Picea glauca (Moench) A. Voss) 


\section{Abstract}

Northern hardwood selection silviculture relies on the perpetuation of natural regeneration.

However, many researchers and forest managers have concerns about deficiencies in regeneration and the associated ingrowth and recruitment of advance regeneration under single-tree selection. Given the differences of management application in the Great Lakes region, long-term studies and datasets are critical to understanding of how these systems function and change. Using the Cutting Methods Study, in the Western Upper Peninsula of Michigan, these concerns were investigated with a multi-decadal dataset, for understory tree species composition and density, diversity, recruitment, and age-diameter relationships across management methods. In response to the past three harvest entries, regeneration densities have consistently been affected by overstory basal area; with a positive relationship in the smallest size classes which gradually flatten in the larger size classes. All treatments had a decline in understory sugar maple dominance with the largest changes in the high intensity treatments which also supported the highest species diversity. Moreover, all treatments have a positive age-diameter relationship with a trend of lower recruitment rates in low intensity treatments, and have created and recruited regeneration since the study establishment in 1956. Following 62-years of consistent management, these results suggest that alternative management methods, beyond Arbogast (1957) recommendations, can be applied in comparable northern hardwood forests and can maintain similar regeneration densities with higher species diversity and recruitment. 


\section{Introduction}

Contemporary management of northern hardwood forests commonly uses the selection system to maintain an uneven-aged structure, sustain high-quality timber, and to perpetuate sufficient natural regeneration of multiple species (Nyland 1998). This however has not always been the management for the forests of the Lake States region. Prior to the intensive commercial removals of eastern white pine and eastern hemlock in the 1800s, large portions of the region were forested with a diverse mixture of conifers and hardwoods (Arbogast 1953). Around the turn of the century, hardwood species became market commodities and many of these forests were partially harvested once again (Kern et al. 2014, Kenefic and Kern 2015).

As a result, the US Forest Service sought to increase reliable information on partial cutting methods in northern hardwoods of the Lake States and established the first experimental management study at the Dukes Experimental Forest in 1926 (Eyre and Zillgitt 1953). Further investigations into even- and uneven-aged management of second-growth forests were established in the 1950s at the Argonne Experimental Forest (AEF) (Stoeckeler 1955, Strong et al. 1995) and at the Ford Forestry Center (now the Ford Center and Forest) at Michigan Technological University (Bourdo 1957). Early results and suggestions of Eyre and Zillgitt (1953) were integrated into a marking guide and management recommendations for northern hardwoods to sustain good yields of high-quality timber while maintaining regeneration of uneven-aged stands under the selection system (Arbogast 1953, Arbogast 1957). The use of this guide has become prevalent in the region (Pond et al. 2014) and is now conventionally known as the "Arbogast Guide". 
From single-tree selection to gap or patch selection, the removal of individual trees creates variable-sized canopy gaps which increases light, nutrient, and growing space availability to promote the recruitment of younger age classes (Ashton and Kelty 2018). Despite the profound differences, all of these selection variations preferentially removes trees with high mortality risk, cull, poor quality or form, or that interfere with stand development (Eyre and Zillgitt 1953, Arbogast 1957). The selection system is primarily evaluated by the species and uneven-aged structural patterns of the overstory, as that is the layer that is actively manipulated (Reed and Mroz 1997). As such, the effectiveness of the silviculture is commonly only quantified with overstory characteristics such as species diversity, stocking, yield, quality, and vigor (Crow et al. 2002, Leak and Sendak 2002, Neuendorff et al. 2007). Furthermore, overstory dynamics only show individuals that have survived stem exclusion (Oliver and Larson 1996) and have obtained dominance and individuals that were not marked and removed during timber harvests.

As it has been less than a century since the introduction and broad application of the selection system in the northern hardwoods of the Lake States, researchers, foresters, and silviculturists have continually tested and adjusted this working hypothesis, as to not create a management doctrine (Ashton and Kelty 2018). Likewise, the recommendations of Arbogast (1957), defined by the stocking of basal area and trees per acre in a reverse-J or rotated sigmoid shaped diameter distribution, have been evaluated across forest ownership types in this region. With stands managed under the selection system with residual basal areas greater than $70 \mathrm{ft}^{2} \mathrm{ac}^{-1}$ and maximum diameters greater than 17 inches, Goodburn and Lorimer (1999) found 70\% stand compliance with the guide, whereas Pond et al. (2014) concluded that $65 \%$ of stands complied. Additionally, concerns regarding structure 
homogenization (Crow et al. 2002, Leak and Sendak 2002), species diversity loss (Angers et al. 2005, Neuendorff et al. 2007, Webster et al. 2018, Walters et al. 2020), and declining sustainability due to inappropriate management (Bassil et al. 2019, Henry et al. 2021) have been voiced.

Publications resulting from the Argonne Experimental Forest and Ford Center and Forest long-term studies have been focused on financial analysis of overstory yield and quality improvement, structure, and composition. Early results from the AEF showed that a residual basal area of $75 \mathrm{ft}^{2} \mathrm{ac}^{-1}$ had the greatest harvest values and quality improvement (Erdmann and Oberg 1973, Niese and Strong 1992); however, starting with the fourth harvest entry, the $60 \mathrm{ft}^{2} \mathrm{ac}^{-1}$ residual basal area treatment surpassed the former in harvest value and yield (Niese et al. 1995, Strong et al. 1995, Strong 1999, Draper 2021). In comparison, results from the Ford Center and Forest study have consistently showed that a diameter-limit of 16-in, has the best combination of harvested log grades, volumes, and financial returns (Reed et al. 1986, Erickson et al. 1990, Draper and Froese in press). Similarly, both studies have experienced increases in the relative abundance of sugar maple in the overstory of all treatments, with the singular exception of the 16-in diameter-limit treatment at the Ford Center and Forest (Bodine 2000, Previant 2015, Draper 2021). The few studies that have focused on regeneration have reported that selection treatments at both sites have sustained well-stocked understories (Metzger and Tubbs 1971, Bodine 2000); however, more intense treatments (diameter-limits and clearcuts) have resulted in more variable regeneration and increased cover of weedy and herbaceous species (Metzger and Tubbs 1971, Campione et al. 2012). 
As the composition of the overstory directly affects the composition of the understory by creating propagules (Tubbs 1977), both layers are intricately involved with each other (Fisichelli et al. 2014). However, the role of the understory on long-term results is notably understudied. Consequently, there is minimal guidance in existing literature for managing tree regeneration in the understory. When the understory has been studied, results are more difficult to compare as they are often single-year data which are reported as percent stocking of desirable and undesirable tree species (Metzger and Tubbs 1971, Walters et al. 2020). Additionally, quadrat sampling designs that are commonly used for collecting percent stocking data are known to underestimate the true population as they do not capture the spatial heterogeneity of size class growth patterns under selection silviculture (Avery and Burkhart 2002, Nyland 2016, Ashton and Kelty 2018).

The disproportionate abundance of overstory research including silviculture experiments, landscape studies (Neuendorff et al. 2007, Webster et al. 2018), and recent papers (Bassil et al. 2019, Walters et al. 2020) highlight the issues that result from making speculations about tree regeneration dynamics in the understory. Especially with the aforementioned varying application of Arbogast (1957), questions remain regarding the response of northern hardwood regeneration in the understory to selection silviculture.

Repeated sampling, as present in long-term datasets offer better insights into the consequences of the application of the selection system and other partial cutting methods on second-growth forests. Forest structure, species diversity, sustainability, and additionally regeneration and recruitment have been investigated with the Cutting Methods Study at the Ford Center and Forest. Bodine (2000) found that there was a loss of species 
diversity from the seedling to the sapling size class, regardless of management; and suggested that even though sapling densities (3-5 in dbh (diameter at breast height)) did not differ, recruitment could be affected by treatment type. Understory species diversity loss was also reported by Neuendorff et al. (2007), with the additional hypothesis that single-tree selection is creating sugar maple monocultures. Moreover, Previant (2015) not only concluded that the harvests were insufficient to regenerate or recruit species other than sugar maple, but also suggested that diameter-limit thinnings 'ignore' low vigor trees which weaken the age-size relationship as compared to selection treatments. Additionally, Previant (2015) suggested that there was a lack of post-1957 recruitment as the overstory age structure predated the 1938 commercial harvest.

This study follows up on a long-term northern hardwood management gradient study to first, maintain continuity of the research and dataset regarding species composition, density, and diversity of the understory; secondly, to assess regeneration age structure and recruitment in the understory; and lastly, to contribute in parallel to the overstory growth and yield analyses completed by Draper (2021). Although the understory is most generally defined as 'all forest vegetation growing under an overstory' (SAF 2018), this study uses understory to characterize only live tree regeneration below the overstory $(<5$-inch $\mathrm{dbh})$, including first-year germinant seedlings.

It was expected that repeated partial cuttings affects the composition, density, and recruitment of tree regeneration by increasing the amount of growing resources available in the understory. If true, harvest intensity influences species survival and growth by maintaining higher resource availability in the understory, wherein less tolerant species can 
better compete with more tolerant species. This was evaluated by using pre-harvest understory tree regeneration data for the 1998 and 2008 entries and data from the 2018 entry collected in 2020 to compare species composition and density across time; and by analyzing the age structure of sugar maple regeneration to compare the age-diameter relationships between treatments. Statistical testing could not be performed due to a lack of treatment replication; however, comparisons between partial cutting methods can be made to assist and guide future research and management. 


\section{Methods}

\subsection{Site Description and Study Area}

The Cutting Methods Study is a long-term silvicultural experiment, located in Alberta, Michigan (46.6448, -88.4812) on the Ford Research Forest, managed by the College of Forest Resources and Environmental Science at Michigan Technological University. The original study was established in 1956-57 to evaluate the growth response of northern hardwoods in response to heavy commercial thinnings to help create guidelines for optimizing growth and yield using the selection system (Bourdo 1957).

Soils at the Cutting Methods Study are classified as Allouez gravelly coarse sandy loam with slopes varying between 0 and 6 percent, and support a site index between 50 and 60 $\mathrm{ft}$ (base age 50) (Berndt 1988). The temperate climate has an average annual temperature of $40.6^{\circ} \mathrm{F}$, receives an average of 34.5 inches of precipitation, and 147.6 inches of snowfall (Lawrimore et al. 2016).

The Cutting Methods Study and surrounding forest were once pine-hardwood forest but the pine was heavily harvested in the late 1800s (Bourdo 1957). Prior to land ownership change, Ford Motor Company implemented a heavy commercial cut between 1938 and 1946 on over 75,000 acres, which was estimated to have removed $75 \%$ of merchantable sawtimber volume and $92 \%$ of the estimated value (Bourdo 1957). The residual forest in the study area contained cull and phenotypically defective canopy trees and a 'fair' stocking of small sawtimber and pole size trees $(\leq 16$ in $\mathrm{dbh})$ of which the latter was estimated to have originated from the harvest in the late 1800s. Additionally in 1956, the age of the 2-4-inch dbh size class was estimated to be 20 years, which corresponds to the 
1930s harvest (Bourdo 1957). These commercial partial harvests resulted in the residual forest and regenerating trees being composed of a mixture of the following species: sugar maple (Acer saccharum Marsh), yellow birch (Betula alleghaniensis Britton), American elm (Ulmus americana Linnaeus), with minor components of red maple (Acer rubrum Linnaeus), American basswood (Tilia americana Linnaeus), black cherry (Prunus serotina Ehrhart), hophornbeam (Ostrya virginiana (Miller) K. Koch), Eastern hemlock (Tsuga canadensis (Linnaeus) Carrière), balsam fir (Abies balsamea (Linnaeus) Miller), and white spruce (Picea glauca (Moench) A. Voss).

\subsection{The Cutting Methods Study}

The study area covers a total of 54.8 acres and consists of nine treatment units ranging in size from 3.6 to 14.4 acres. Each unit was assigned one of eight experimental treatments: (1) single-tree selection to one of three residual basal areas (50, 70, and $\left.90 \mathrm{ft}^{2} \mathrm{ac}^{-1}\right)$; (2) cutting above one of four threshold diameter limits $(5,12,16$, and 22 in); (3) a "light improvement" focused on improving residual stand quality; and, (4) an uncut control (Figure 7-1).

Detailed descriptions of the experimental treatments follow, as described in Bourdo (1957), (Table 7-7). The control unit has remained unharvested since the establishment of the study. The light improvement (LI) is managed with the focus of removing trees with undesirable traits such as defects, poor quality, and form.

The three selection (STS) treatment units are managed under the single-tree selection method with a maximum stand diameter of 24 in, and residual basal area, in trees greater than 5 inches dbh, of $90 \mathrm{ft}^{2} \mathrm{ac}^{-1}, 70 \mathrm{ft}^{2} \mathrm{ac}^{-1}$, and $50 \mathrm{ft}^{2} \mathrm{ac}^{-1}$ (STS 90, STS 70, and STS 50, 
respectively). Individual trees are removed to meet the stocking guide when they exhibit 1) cull, defects, and/or high risk of mortality, 2) poor form, quality, and/or vigor, 3) interference with stand development potential, or 4) greater than 24 inches dbh (Eyre and Zillgitt 1953, Arbogast 1957). It is important to note that previous to 1998 , only trees 10 inches dbh and greater were considered when determining residual stocking; consequently, pre-1998 harvests had slightly higher residual basal areas overall (Bodine 2000).

Each of the four diameter-limit (DL) treatment units are managed using dominant thinning down to $22,16,12$, and 5 inches $\mathrm{dbh}$. In each of these units, all trees equal to and greater than the diameter-limit are removed. In the diameter-limit cuttings, tending was confined to trees above the diameter-limit, with no tending below, regardless of quality, form, or defect (Draper and Froese in press).

The treatments are managed to these specifications on a ten-year harvest cycle. However, treatments are not harvested when merchantable volume makes the entry economically infeasible. In addition to the regular harvest schedule, a salvage harvest in 1980 was implemented in all treatments except the DL 5, LI, and control, to remove dead and dying American elm that were detrimentally affected by Dutch Elm Disease ${ }^{1}$ (Bourdo 1957, Erickson et al. 1990).

Within each treatment, a one-acre permanent overstory measurement plot was established and divided into ten square $1 / 10$-acre subplots which run in a north-south orientation

\footnotetext{
${ }^{1}$ Dutch Elm Disease is a disease complex from a combination of a fungus and an elm bark beetle. The fungus can be either Ophiostoma ulma or Ophiostoma novo-ulma. The elm bark beetle can be one of the following: Hylurgopinus rufipes, Scolytus multistriatus, or Scolytus schevyrewi (Grabowski 2019).
} 
(Figure 7-1) (Bourdo 1957). Prior to and after each harvest year, within the ten subplots of each treatment, the following data were collected for all trees greater or equal to 5 inches dbh; species, dbh, total height, merchantable height (to a 4-in outside bark diameter), merchantable sawlog height (to a 10-in outside bark diameter), percent soundness and cull, and butt-log grade for sawtimber trees (Draper 2021).

Before the establishment cut, the regeneration in each treatment unit was measured. Saplings under 5 in dbh were tallied by species and 1-inch size classes using four 1/60-acre subplots located on the east or west sides of the one-acre plots. Seedlings were tallied by species and height class $(<0.5 \mathrm{ft}, 0.5-3 \mathrm{ft},>3 \mathrm{ft}$ and $<0.5 \mathrm{in} \mathrm{dbh})$ using four $1 / 4$-milacre subplots located 23 feet diagonally from the one-acre plot center (Bourdo 1957). However, starting in 1998 (Bodine 2000), regeneration greater than 1 foot in height and less than 5 in dbh were tallied with one fixed-radius $1 / 50$-acre sapling plot at the one-acre plot center; and seedlings less than 1 foot in height were tallied with three fixed-radius $1 / 1000$-acre small seedling plots, 25 feet from plot center at $0^{\circ}, 120^{\circ}$, or $240^{\circ}$ (Figure $7-2$ ).

\subsection{Field and Laboratory Methods}

\subsubsection{Structure and Composition}

Understory species compositions and densities were calculated for the 1998, 2008, and 2018 harvest cycles from data collected in the permanent regeneration sampling plots. The pre-harvest 1998 data were reproduced from Bodine (2000), pre-harvest 2008 data were retrieved from the Cutting Methods Study database, and most recently, we collected understory data after the 2018 harvest entry during the summer of 2020 . Within the circular 1/50-acre sapling plot, starting at true north and sweeping clockwise with a tape of the plot 
radius, every live tree was tallied by species and by size class. These size classes are defined as the following according to Bodine (2000):

- Medium seedlings: 1.0 to 3.0 feet in height

- Large seedlings: $>3.0$ feet in height and $\leq 0.9$ inches diameter at breast height

- Small saplings: 1.0 to 2.9 inches diameter at breast height

- Large saplings: 3.0 to 4.9 inches diameter at breast height

In the three circular 1/1000-acre seedling plots, all tree species below 1.0 foot in height were tallied by species.

To easily distinguish and compare the treatments, each unit was classified into a harvest intensity class based on the proportion of basal area removed during the 1998 (Bodine 2000), 2008 (Previant 2015), and 2018 (Draper 2021) harvests from the pre- and postharvest overstory stocking. Other than the control, if a treatment was not harvested, the corresponding $0 \%$ basal area removal was not included in this calculation (Table 7-1). The three classes and the associated treatments are as follows: low intensity $(\leq 15 \%$; control, LI, STS 90, DL 22), medium intensity (16-30\%; STS 70, STS 50, DL 16), and high intensity (> 30\%; DL 12, DL 5). In some analyses, size classes are as defined by Bodine, while in others size classes have been further categorized into three size classes. These larger classes are as follows; small seedlings $(<1 \mathrm{ft}$ tall $)$, large seedlings $(>1 \mathrm{ft}$ tall, $<1$ in dbh), and saplings (1-5 in dbh). Statistical testing was not utilized due to the un-replicated nature of the treatments. 


\subsubsection{Sugar Maple Age Structure}

Age structure in the understory was assessed by sampling a small number of trees destructively. To ensure continuity of the long-term experiment and dataset, sample trees were selected from outside the permanent measurement blocks but within the treatment unit receiving the same, uniform experimental treatment. Trees were selected using a stratified random sample of two trees from each of the same size classes as used in the tree tallies, with the exception of the small seedling size class. Therefore, a total of eight trees were destructively sampled in each treatment unit.

To select trees, the nearest tree to a quasi-random sample point was selected for sampling, and new sample points were generated until two sample trees had been obtained for each size class. Points were located by taking a random azimuth from at least one chain in from the treatment edge, and pacing another chain. If the transect led to a location within one chain of the treatment boundary (i.e., within the transition to an adjacent treatment), or into the 1.0-acre overstory plots, the back azimuth was utilized. Sample trees were scored at stump height (1 foot) and at breast height (4.5 feet) if possible, and labeled with a unique identifier. Sample trees were cut as close to the ground as possible and at least 2 inches above breast height, and the approximately 4' length stem segments were collected for future processing.

In the lab each stem segment was dried at $65^{\circ} \mathrm{C}$ for 7 days, then cut at the bottom and top into 3 to 4 -inch length segments with counting faces at stump height and breast height. The counting faces were sanded using successively finer paper down to 400 grit and scanned on a document scanner at $4800 \mathrm{dpi}$. Annual rings (up to latewood of 2019) were counted 
using CooRecorder 9.5 software (Cybis Elektronik \& Data AB 2018), each segment counted twice along two radii $120^{\circ}$ apart, and minimum-maximum ages were estimated.

\subsection{Analyses}

Treatments were compared using regeneration densities and diversity measures. By comparing decadal stem densities to pre-harvest overstory basal area of trees greater than 12 in dbh, representing the most dominant canopy trees, the effect of residual stand density on regeneration levels within size classes was compared across treatments.

Stem density (stems $\mathrm{ac}^{-1}$ ) averages and standard deviations were calculated for each size class and treatment for the 2008 and 2018 harvest entry cycle. The small seedling $(<1 \mathrm{ft}$ tall) class was averaged across each of the 30 1/000-ac subplots, while the large seedling ( $>1 \mathrm{ft}$ tall, $<1$ in $\mathrm{dbh})$ and sapling $(1-5$ in $\mathrm{dbh})$ size classes were averaged across the ten 1/50-ac regeneration plots. Diversity measures were only calculated for 2008 and 2018 due to a lack of access to the inventory data of the 1998 harvest entry cycle. Average species richness (S) and standard deviation were calculated for each of the size classes and treatments. The average Shannon-Wiener's Diversity Index/entropy $\left(\mathrm{H}^{\prime}\right)$ and standard deviation were also calculated for each of size classes and treatments. Species richness (S) and entropy (H') were calculated using the specnumber and diversity functions of the 'vegan' package (Oksanen et al. 2020) in R 3.6.0 software (R Core Team 2019).

Treatment effects on germination and recruitment were assessed by comparing the regeneration frequency within each treatment and size class across the 1998, 2008, and 2018 harvest cycles. Additionally, treatment effects on the age distribution of sugar maple regeneration was assessed by comparing the relationship between age and diameter, at 
stump and breast-height, in each treatment. Zero-intercept simple linear regression models were created using the ' $I m$ ' method within the 'ggplot2' data visualization package in R (Wickham 2016) and the coefficients of determination were adjusted using Kozac and Kozac (1995). Additionally, the number of years to reach breast height was calculated for each tree and treatment differences were compared using boxplots.

The dynamics between the overstory and understory as affected by treatment were assessed by comparing the change of sugar maple dominance. These overstory and understory data were collected from the pre-establishment report (Bourdo 1957), data from before the management diameter change in 1998 (Bodine 2000), and the latest 2018 harvest data collected in 2020. 


\section{Results}

\subsection{Density and Structure}

Regeneration average stem densities for all species by size class and treatment are presented with standard deviations in Table 3-1 for the 2008 and 2018 harvest cycle, and additionally average stems per acre by size class, species, and treatment in the appendix for 1998 (Table 7-4), 2008 (Table 7-5), and 2018 (Table 7-6).

\subsubsection{Small Seedlings $(<1 \mathrm{ft}$ tall $)$}

Before the 2008 harvest, all active treatments had an average small seedling density of 11000 stems ac$^{-1}$, with the lowest occurring in the DL $5\left(2500\right.$ stems ac$\left.^{-1}\right)$ and highest in the STS 90 (22500 stems ac $\left.{ }^{-1}\right)$, compared to the 46500 stems ac$^{-1}$ in the control. However, by the time of the 2018 harvest cycle these dynamics had shifted. The small seedling density increased in all managed treatments to an average of 245000 stems ac ${ }^{-1}$ compared to 432000 stems ac $^{-1}$ in the control. The lowest density still occurred in the DL 5 (23000 stems ac ${ }^{-1}$ ), but the DL 22 had the highest density with 500000 stems ac ${ }^{-1}$ (Table 3-1).

Across the past three harvest cycles, regeneration stem densities have been consistently affected by overstory basal area (Figure 3-1). Of the STS treatments, the STS 90 had the highest small seedling density, followed by the STS 70 and STS 50, with the exception of the STS 50 in 1998 having a greater density than STS 70. The four diameter-limit treatments appear to have a similar pattern of decreasing densities with the lower limits, with more variation in the 2008 entry cycle. The positive relationships in the small seedling class flattens as the size classes increase. 


\subsubsection{Large Seedlings (1-3 ft tall, $>3 \mathrm{ft}$ and $<1$ in $\mathrm{dbh})$}

Within the selection treatments, stem density trends negatively with residual basal area, with higher densities occurring in the STS 50 with sequential decreases in the STS 70 and STS 90. However, in the diameter-limit treatments, higher limits consistently had the greatest stem densities of large seedlings with the lowest density occurring in the DL 5 . The LI had the highest density of large seedlings across all treatments in 2008, with the control surpassing this in 1998 and 2018. In Figure 3-1, with the smaller size classes, the relationship between the regeneration densities and overstory basal area becomes ambiguous in the medium seedling size class shown in the 2008 data.

\subsubsection{Saplings (1-3 in dbh, 3-5 in dbh)}

In the sapling layer, there is a slight negative relationship between stem density and overstory basal area. Unlike the previous size classes, there appears to be no trends within the selection and diameter-limit treatments between stem density and overstory basal area. In 1998, the STS 90 had the highest density of 450 stems ac $^{-1}$ and DL 22 at the lowest of 190 stems ac ${ }^{-1}$, with the control having $95 \mathrm{stems} \mathrm{ac}^{-1}$. After a decade, the 2008 sapling density was the highest in the DL 12 (505 stems ac$\left.{ }^{-1}\right)$, lowest in the DL 5 (135 stems ac ${ }^{-1}$ ), compared to the $165 \mathrm{stems} \mathrm{ac}^{-1}$ of the control. Again in 2018, the control had the lowest overall density of 260 stems ac$^{-1}$; in the active treatments, the DL 16 had the lowest of 290 stems ac ${ }^{-1}$ and the highest was $695 \mathrm{stems} \mathrm{ac}^{-1}$ in the DL 5. 


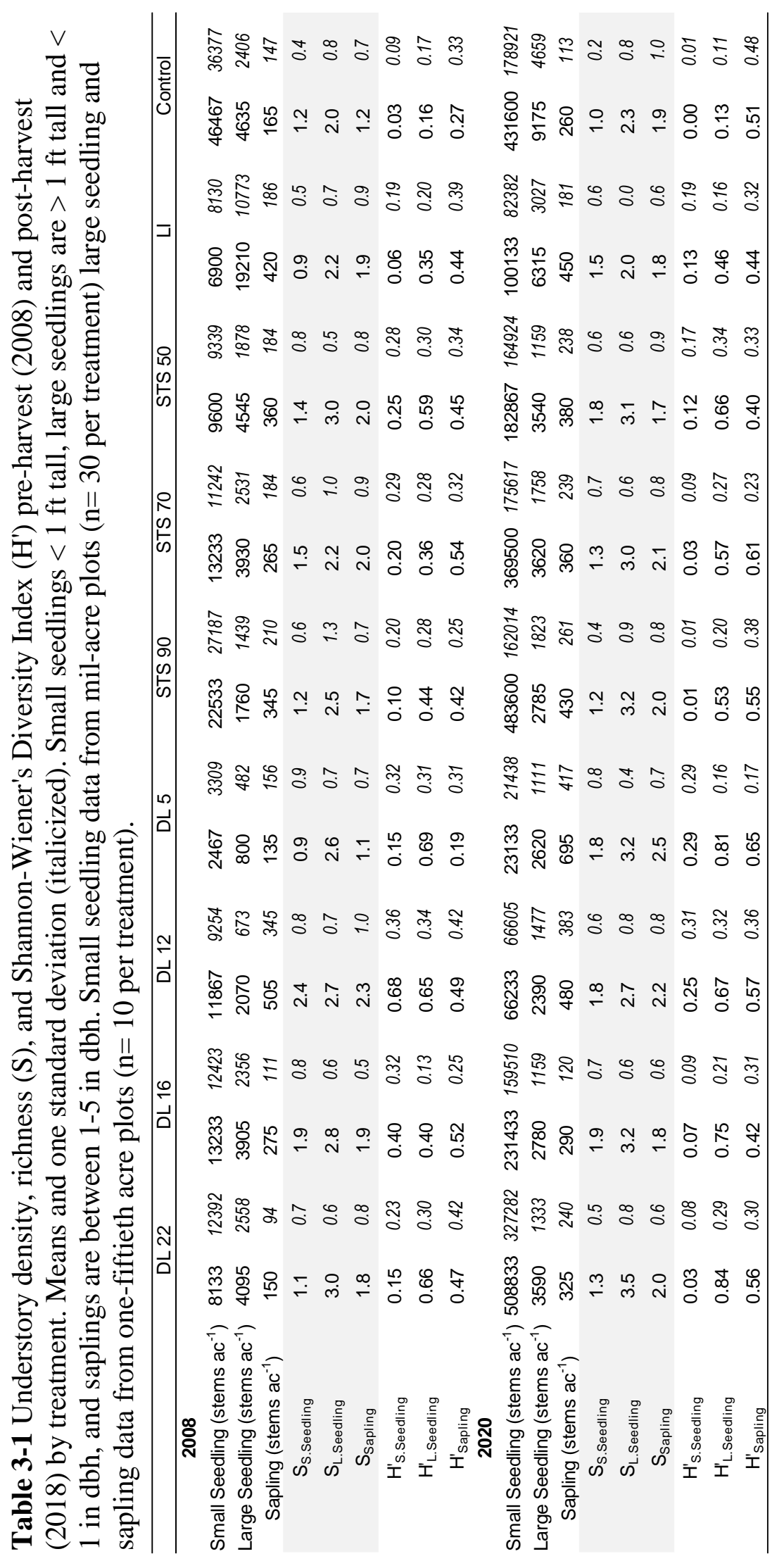




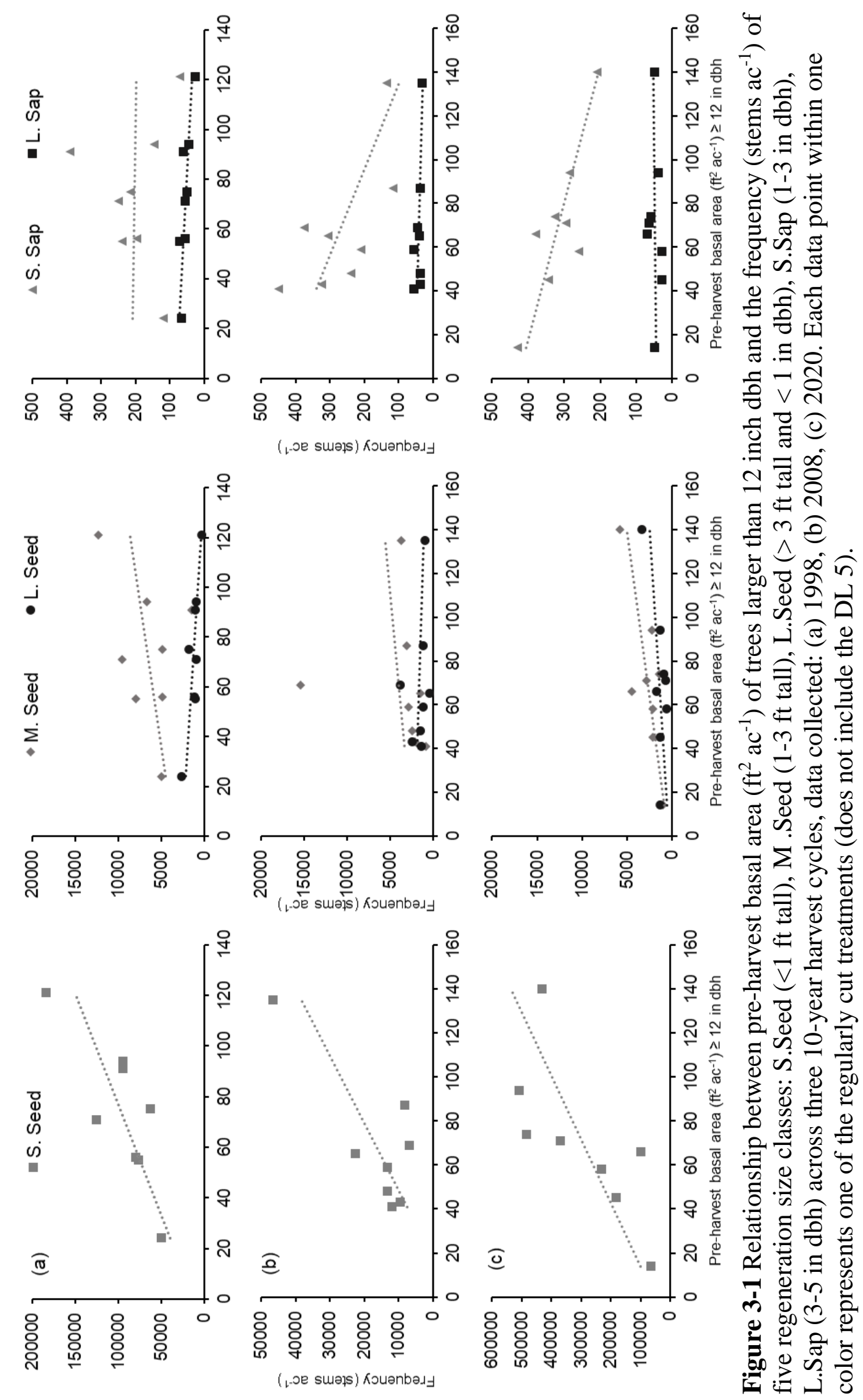




\subsection{Species Composition}

Species relative abundances across the past three harvest cycles are shown for 1998, 2008, and 2018 in Table 3-2. From the beginning of the study, sugar maple has been the dominant tree species in the overstory and understory.

In the small seedling size class, sugar maple has consistently been the dominant species $(80-100 \%)$ in all treatments across the past three harvest cycles, with the exception of the 12 DL and 5 DL in the 2008 entry with $29 \%$ and $69 \%$ respectively. In the large seedling size class, sugar maple dominance has varied slightly across the past three entry cycles. In 1998, all treatments contained between $87-99 \%$ sugar maple with the only exception being the DL 12 with 50\% sugar maple stems in the large seedlings class. Similarly, in 2008 all treatments had $73-97 \%$ sugar maple besides the lowest percentages of $19 \%$ and $63 \%$ occurring in the DL 12 and 5 respectively. In response to the 2018 entry cycle, all the treatments had between $71-96 \%$ with the exceptions of the DL 22 with $60 \%$, DL 12 with $9 \%$, and DL 5 with $64 \%$. Across the three cycles, the control has consistently contained the most sugar maple with over $95 \%$, and the lowest sugar maple occupancy was always in one of the high intensity treatments, specifically the diameter-limit treatments. Additionally, the diameter-limit treatments had more variance than the single-tree selection treatments.

Across cycles and treatments, sugar maple dominance has been highest in the smallest size class and lowest in the largest understory size class. In the sapling layer (1-5 in dbh), the percentage of sugar maple has decreased across these entry cycles in all treatments except in the STS 70 which had an increase of $10 \%$ between the 2008 and 2018 harvest. 
Consistently, the DL 12 had the lowest percentage of sugar maple in 1998 (57\%), 2008 (16\%), and 2018 (13\%). The highest sugar maple dominance for both the 1998 and 2008 entry occurred in the control with $95 \%$ and $79 \%$ respectively, but the DL 16 had the highest following the 2018 entry of $67 \%$.

The distribution of these species by size class and treatment for 1998, 2008, and 2018 can be compared in Figures 3-2, 3-3, and 3-4. Not only is there a visible difference between the 2008 and 2018 percentages of these species such as the shifting pattern of hophornbeam and black cherry, but the changes of sugar maple dominance as displayed by the values atop the bars. Across these harvest cycles, sugar maple dominance has decreased in the larger size class in all treatments with only a few exceptions of a slight increase.

Across these three layers of the understory, the high intensity treatments have resulted in the largest change of sugar maple dominance. Between 1998-2008 and 2008-2018, the DL 12 had an average change of $64 \%$ and $21 \%$ in the small seedling $(<1$ foot tall) and large seedling ( $>1 \mathrm{ft}$ tall, $<1 \mathrm{in}$ dbh) size classes; the smallest change occurred in the low intensity treatments of the STS 90, LI, and control. The large seedling size class had the least variance between treatments followed by the sapling (1-5 in dbh) and small seedling size classes.

Besides sugar maple as the dominant species in the understory, the dynamics within the other present species are just as important. The only other species that can be found in every treatment and through the 3 harvest cycles is black cherry. Prior to the 1998 harvest, black cherry was not present in the sapling size class with the exception of the STS 50 and LI. In the 2008 inventory, black cherry was not present in the sapling size class in the DL 
5, STS 70, and control. Following the harvest of 2018, black cherry was absent from the small seedling size class in the control, and the sapling size class of the DL 22 and STS 50.

The next abundant species was hophornbeam, which was present in all treatments across harvest years with a few exceptions. In the LI, hophornbeam was present in the small seedling size class in 1998, most of which recruited into the sapling size class by 2008 . Following the 2018 harvest entry, hophornbeam was not present in any of the regeneration size classes. American elm was present in all treatments except for the STS 90 in 2008, but reappeared in all regeneration size classes following the 2018 harvest. In 1998, yellow birch regeneration was present in the sapling layer of the DL 22 and STS 90 of which increased or maintained stem densities in the following decades. In 2008, yellow birch was additionally found in the large seedling layer of the DL 22. Following the 2018 harvest, yellow birch was present in the sapling layer in the STS 90, but in both the large seedling and sapling size class in the DL 22. American basswood regeneration was recorded in all size classes of the DL 12 in 1998, by 2008 was only found in the sapling size class, and was not present following the 2018 harvest entry.

With recurrent management, the shifting regeneration dynamics have not reflected the dynamics of the overstory. The differences in sugar maple dominance between the overstory and understory for 1956, 1998, and 2018 are displayed in Figure 3-5. Starting in 1956, before the original study harvest, the difference of dominance was not equal across the treatment units. The DL 5 unit had the largest difference between the overstory and understory with $49 \%$, followed by the LI with $28 \%$. In contrast, the DL 22 was the only unit which had a negative percent difference, of $-3 \%$. All other units had a positive 
difference between 5-13\%. By 1998, after four 10-year harvest cycles, the differences in sugar maple dominance were not equal. Prior to the 1998 harvest entry, the largest difference of $35 \%$ was in the DL 12. Comparatively, the control had no difference of sugar maple dominance percentage. All other treatments ranged between 2-19\% difference. After the 2018 harvest, all treatments had a difference greater than $10 \%$, with the highest differences found in the DL 12, DL 5, and DL 22 with 45\%, 28\%, and 27\% respectively. Since the start of the consistent management and harvest entries, all treatments have had a greater percentage of sugar maple in the overstory compared to the understory.

\subsection{Richness and Diversity}

Between the 2008 and 2018 harvest entries, all treatments and size classes experienced either no change or an increase in average species richness, with sugar maple present across all size classes and treatments (Table 3-1). In 2008, species richness was the lowest in the small seedling layer (1-2), followed by the sapling layer (1-2), and the large seedling layer (2-3). A decade later, richness still followed the same pattern with the greatest species gain in the sapling layer, specifically in the DL 5 and control. This shift of species richness is a result of recruiting American elm, hophornbeam and black cherry (Table 7-4, 7-5, 7-6). Representing these dynamics differently, the Shannon-Wiener entropy index does not surpass 0.84 as reflected in the large seedling size class of the DL 22 of the 2018 harvest entry. This value corresponds to an average richness of 4 species per acre. 
Table 3-2 Regeneration densities by treatment and size class for (a) 1998, (b) 2008, and (c) 2018 harvest cycles.

\begin{tabular}{cccccccccc} 
All species (a) & \multicolumn{10}{c}{ Treatment } \\
\hline Size Class & DL 22 & DL 16 & DL 12 & DL 5 & STS 90 & STS 70 & STS 50 & LI & Control \\
\hline$<1^{\prime}$ tall & 95000 & 79333 & 49567 & 57167 & 94467 & 62967 & 76367 & 125433 & 184500 \\
1-3' tall & 6695 & 4855 & 4945 & 2295 & 1480 & 4890 & 7930 & 9525 & 12280 \\
$>3$ ' tall, <1" dbh & 860 & 1095 & 2630 & 140 & 1020 & 1730 & 1035 & 925 & 305 \\
1-3" dbh & 145 & 195 & 120 & 265 & 390 & 215 & 240 & 250 & 70 \\
3-5" dbh & 45 & 55 & 65 & 140 & 60 & 50 & 70 & 55 & 25 \\
\hline Sugar maple & & & & & & & & & \\
\hline Size Class & DL 22 & DL 16 & DL 12 & DL 5 & STS 90 & STS 70 & STS 50 & LI & Control \\
\hline$<1$ ' tall & 92900 & 76433 & 43967 & 51933 & 93500 & 61400 & 75133 & 123800 & 184033 \\
1-3' tall & 6005 & 4530 & 3620 & 1975 & 1375 & 4510 & 7340 & 9145 & 12150 \\
$>3$ ' tall, $<1 "$ dbh & 665 & 840 & 180 & 135 & 890 & 1425 & 640 & 535 & 250 \\
1-3" dbh & 100 & 140 & 55 & 200 & 255 & 120 & 155 & 210 & 65 \\
3-5" dbh & 45 & 45 & 50 & 90 & 40 & 40 & 60 & 50 & 25 \\
\hline \hline
\end{tabular}

\begin{tabular}{cccccccccc} 
All species (b) & \multicolumn{10}{c}{ Treatment } \\
\hline Size Class & DL 22 & DL 16 & DL 12 & DL 5 & STS 90 & STS 70 & STS 50 & LI & Control \\
\hline$<1$ ' tall & 8133 & 13232 & 11865 & 2466 & 22531 & 13199 & 9599 & 6899 & 46462 \\
1-3' tall & 2995 & 2410 & 785 & 415 & 1410 & 2835 & 2120 & 15470 & 3675 \\
$>3$ ' tall, $<1 "$ dbh & 1100 & 1495 & 1285 & 385 & 350 & 1095 & 2425 & 3755 & 960 \\
1-3" dbh & 115 & 240 & 450 & 65 & 305 & 210 & 325 & 375 & 135 \\
3-5" dbh & 35 & 35 & 55 & 70 & 40 & 55 & 35 & 45 & 30 \\
\hline Sugar maple & & & & & & & & & \\
\hline Size Class & DL 22 & DL 16 & DL 12 & DL 5 & STS 90 & STS 70 & STS 50 & LI & Control \\
\hline$<1$ ' tall & 6999 & 10766 & 3400 & 1700 & 21798 & 11399 & 7866 & 6733 & 46129 \\
1-3' tall & 2560 & 2260 & 280 & 310 & 1205 & 2630 & 1875 & 14645 & 3595 \\
$>3$ ' tall, <1" dbh & 430 & 1185 & 110 & 195 & 290 & 810 & 1765 & 2630 & 885 \\
1-3" dbh & 65 & 170 & 45 & 60 & 220 & 110 & 205 & 275 & 100 \\
3-5" dbh & 30 & 25 & 35 & 35 & 10 & 20 & 20 & 40 & 30 \\
\hline \hline
\end{tabular}

\begin{tabular}{cccccccccc} 
All species (c) & \multicolumn{10}{c}{ Treatment } \\
\hline Size Class & DL 22 & DL 16 & DL 12 & DL 5 & STS 90 & STS 70 & STS 50 & LI & Control \\
\hline$<1$ ' tall & 508782 & 231410 & 66227 & 23131 & 483152 & 369463 & 182748 & 100123 & 431557 \\
1-3' tall & 2260 & 2120 & 1020 & 1230 & 1440 & 2915 & 2160 & 4510 & 5785 \\
$>3$ ' tall, $<1 "$ dbh & 1310 & 660 & 1370 & 1390 & 980 & 705 & 1355 & 1805 & 3390 \\
$1-3 "$ dbh & 285 & 260 & 430 & 605 & 325 & 295 & 345 & 380 & 210 \\
3-5" dbh & 40 & 30 & 50 & 90 & 60 & 65 & 30 & 70 & 50 \\
\hline Sugar maple & & & & & & & & & \\
\hline Size Class & DL 22 & DL 16 & DL 12 & DL 5 & STS 90 & STS 70 & STS 50 & LI & Control \\
\hline$<1$ ' tall & 506749 & 229177 & 63794 & 18865 & 483152 & 368463 & 180815 & 98557 & 431524 \\
1-3' tall & 1670 & 1595 & 155 & 930 & 1415 & 2455 & 1680 & 3955 & 5650 \\
$>3$ ' tall, <1" dbh & 500 & 370 & 50 & 740 & 800 & 440 & 935 & 1250 & 3195 \\
$1-3 "$ dbh & 105 & 185 & 35 & 125 & 225 & 180 & 155 & 230 & 110 \\
3-5" dbh & 25 & 10 & 25 & 45 & 30 & 35 & 15 & 50 & 40 \\
\hline
\end{tabular}




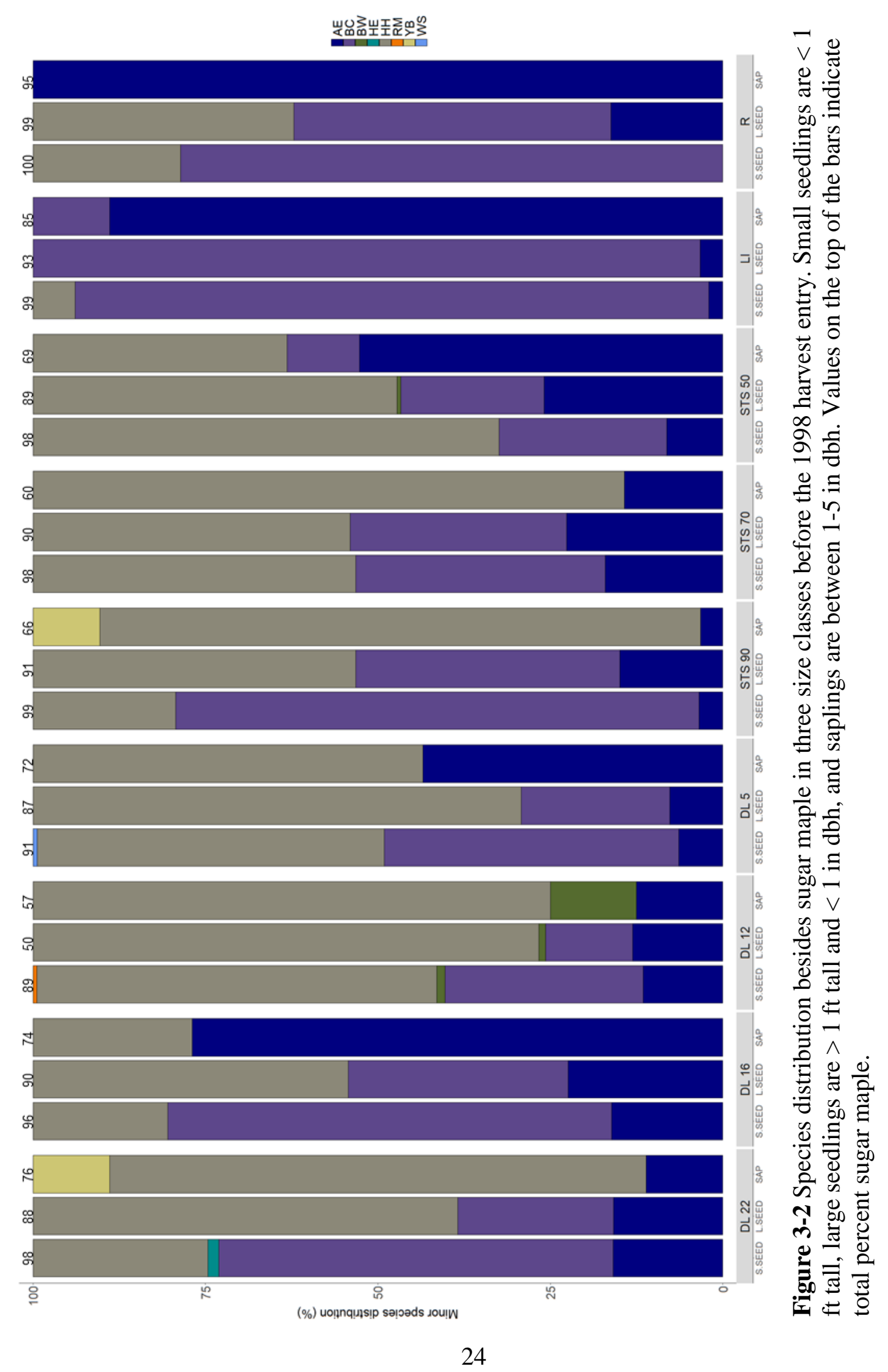




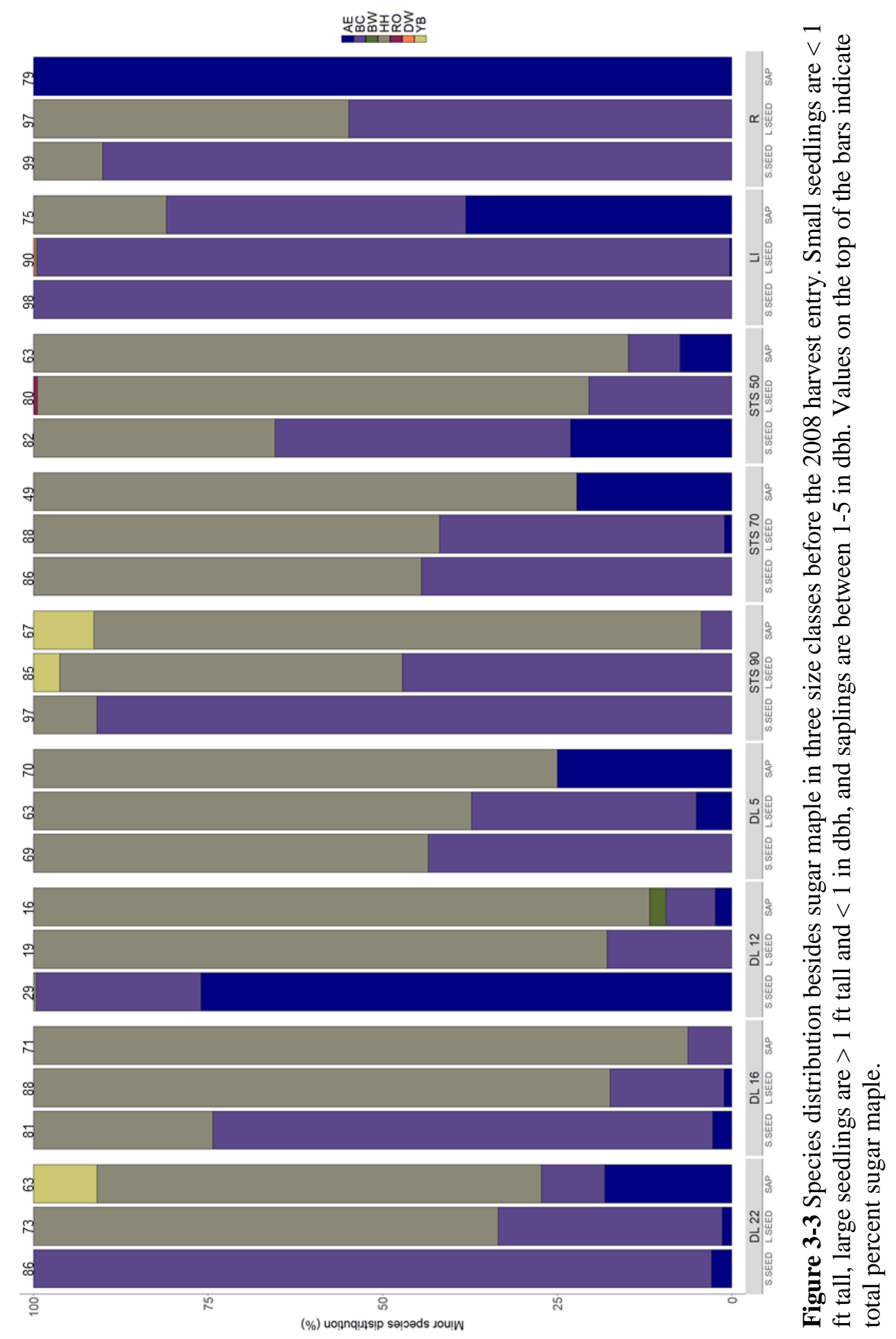




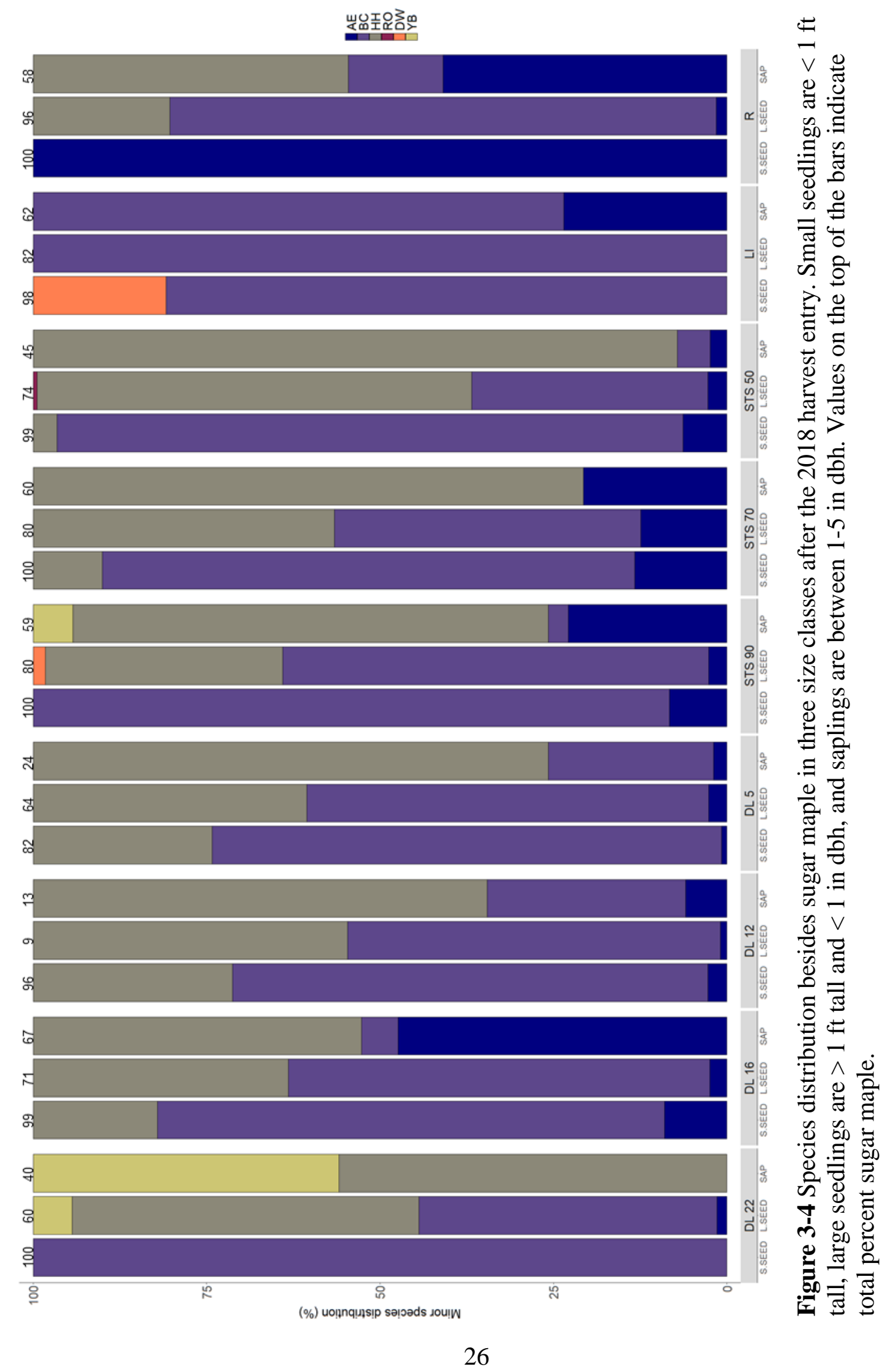




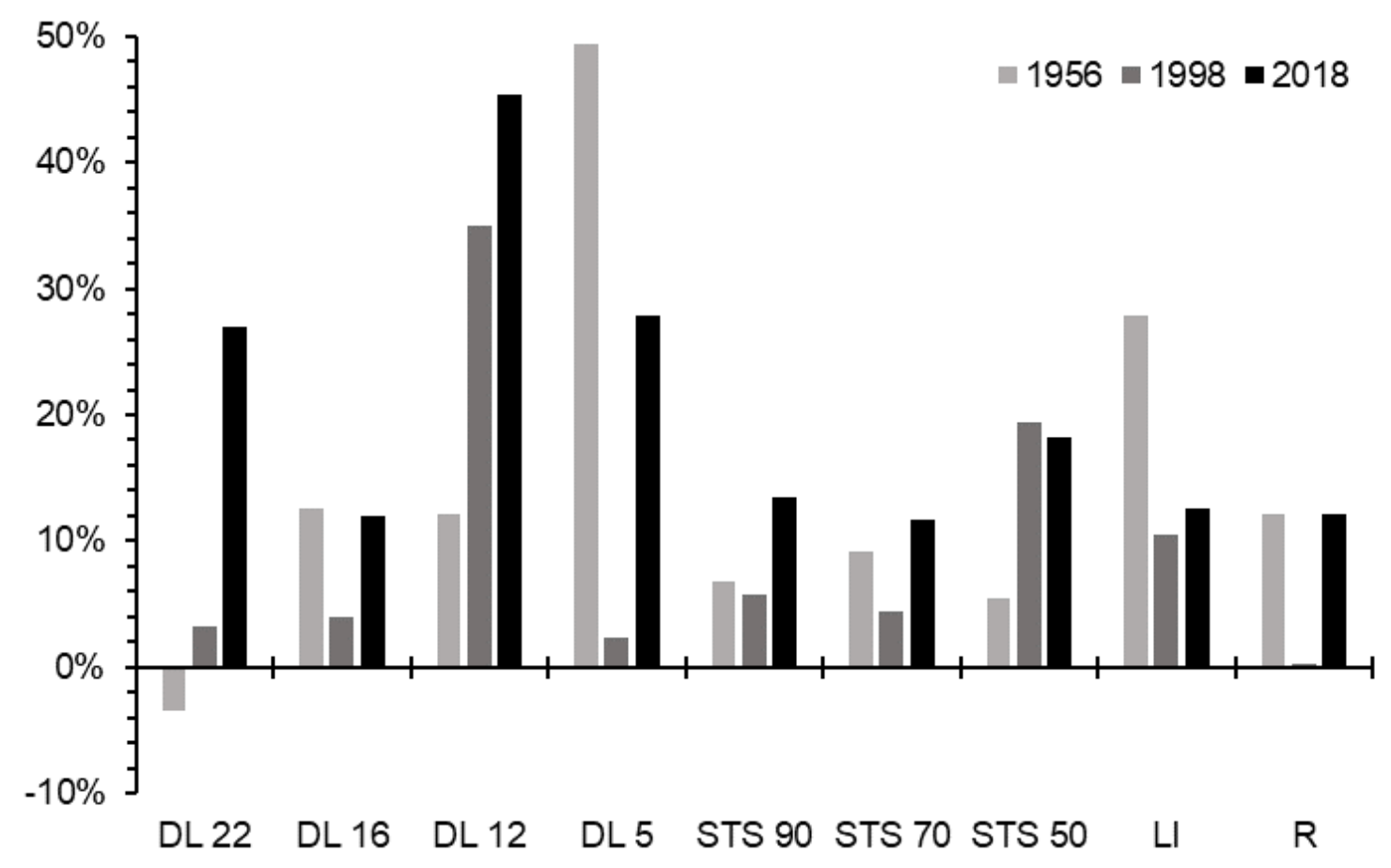

Figure 3-5 Difference between the proportion of sugar maple in the overstory ( $\geq 5$ in $\mathrm{dbh}$ ) and proportion in the understory ( $<5$ in $\mathrm{dbh})$, at the study establishment (1957) as well as the 1998, and 2018 harvest cycles. Positive values indicate greater proportional abundance in the overstory when compared to the understory. 


\subsection{Recruitment and Age}

Most treatments have similar levels of regeneration within size classes and treatments; even with the instability of small seedling densities (Figure 3-6). Even in the control regeneration densities have either remained relatively similar or have increased stem densities in some size classes. As seen in Figure 3-1, the strong relationship between stem densities in small size classes and overstory basal area, specifically in the DL 22 and STS 90, these treatments also have higher levels of mortality between the small seedling and large seedling size classes. In contrast, the high intensity treatments show less consistency of recurring regeneration within size classes (Figure 3-6). The average stem densities across these three harvest years for each treatment in Figure 3-7, shows an interesting dichotomy. Low intensity treatments like the control have higher densities of small seedlings and lower densities of saplings, while the high intensity DL 12 and 5 have the lowest small seedling densities and higher sapling densities.

The age structure of the sampled sugar maple $(\mathrm{n}=55)$ across the nine units revealed a range of maximum ages between 5 and 77 years indicating that new age classes have been continuously created in response to the harvests. Of this sample, only seven saplings (3-5 in dbh) were estimated to have an estimated age over 62 years, which relative to the time of sampling, marks the establishment harvest of 1956-57. The age-diameter relationships shown in Figure 3-8 and 3-9 reveal differences of recruitment between treatments. Visualized by the regressions in Figure 3-8, recruitment to the overstory from 4.5 feet tall occurs fastest in the high intensity treatments, slowest in the control and the higher diameter-limits. The STS treatments and LI occur in between with a general trend of slower 
growth in higher residual treatments. Using the breast height age-diameter regression and years to breast height, an age estimation for a 5 -in dbh sugar maple was calculated and it took close to 100 years to reach the overstory in the control, while it took just over 50 years in the DL 12 and 5 (Table 3-3). Median years to breast height in the boxplots increased in treatments with higher overstory residual basal area (Figure 3-10). 

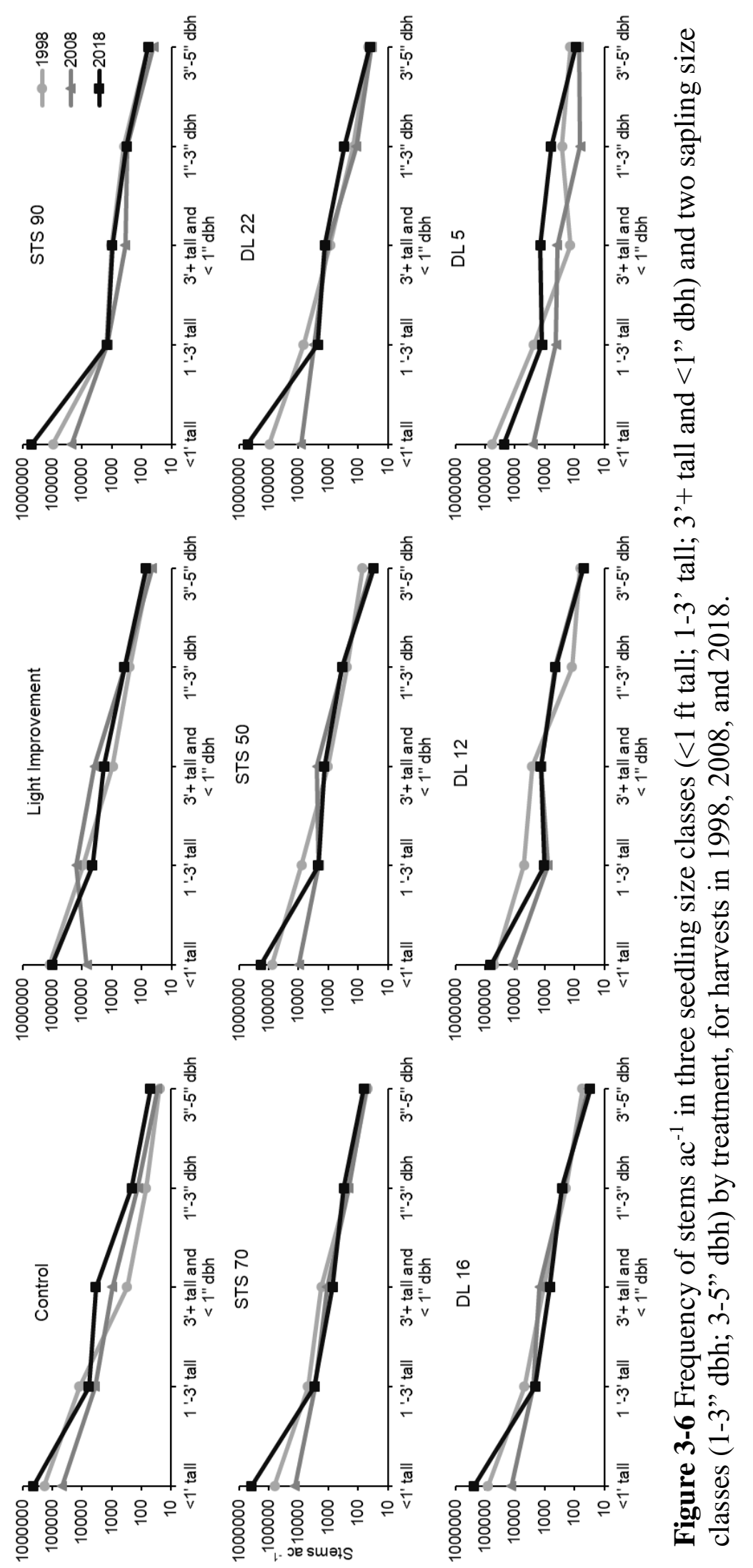


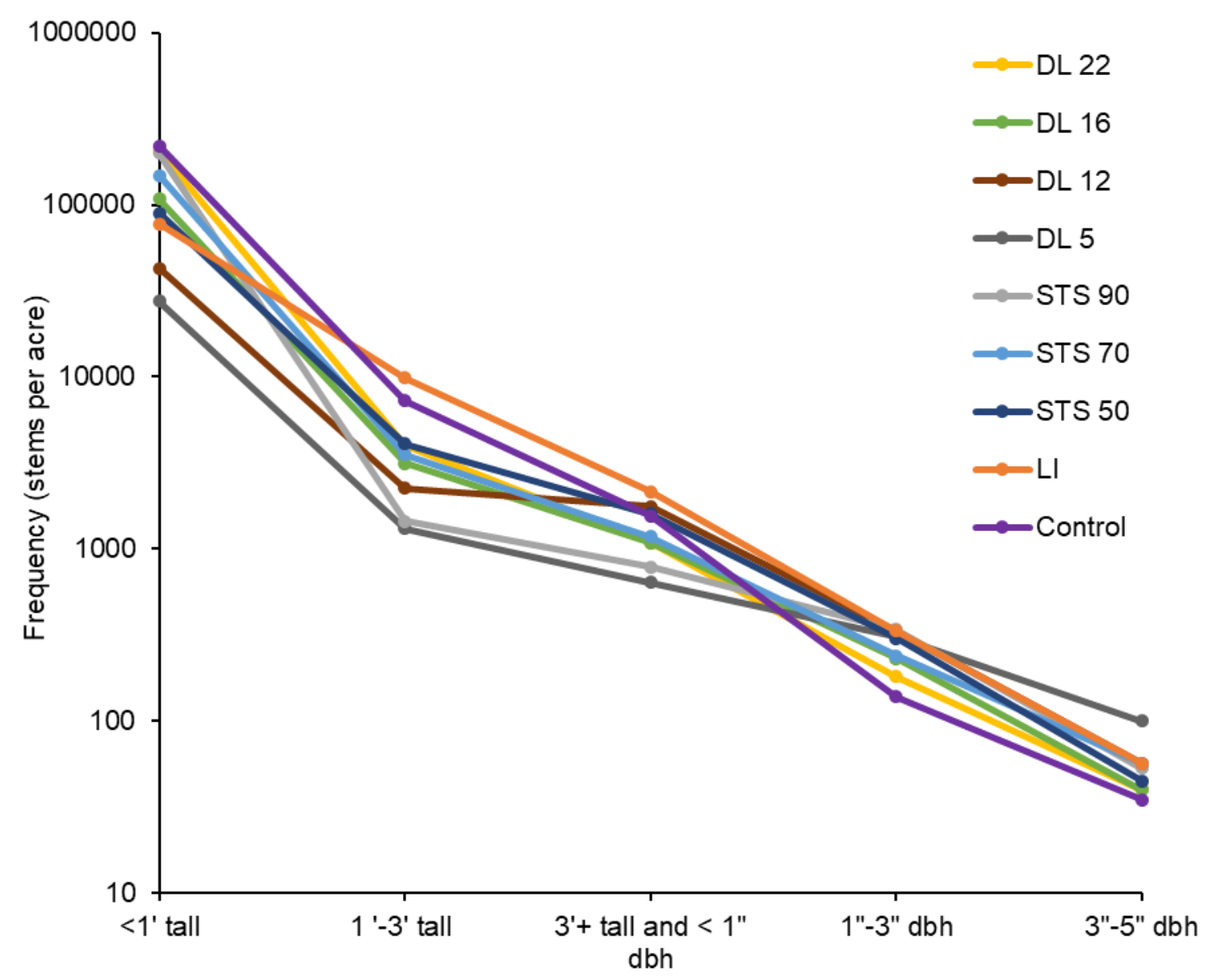

Figure 3-7 Average frequency of stems ac ${ }^{-1}$ across 1998, 2008, and 2018 harvest entry in three seedling size classes ( $<1 \mathrm{ft}$ tall; $1-3$ ' tall; 3'+ tall and $<1$ ' dbh) and two sapling size classes (1-3" dbh; 3-5" dbh) by treatment. 


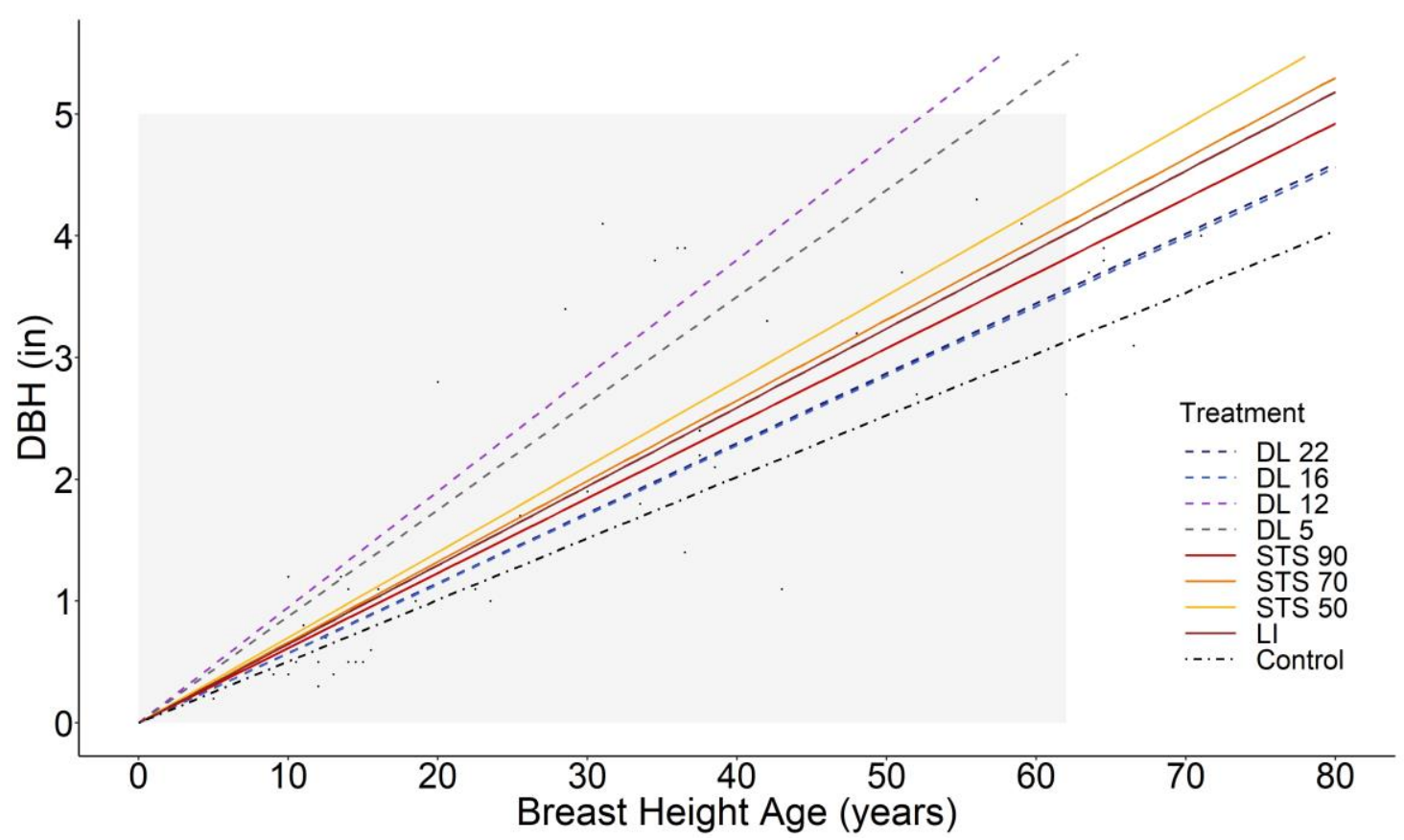

Figure 3-8 Relationship between breast height annual ring count (years) and diameter at breast height (in) for sugar maple regeneration $(\mathrm{n}=50)>1 \mathrm{ft}$ tall and $<5$ in dbh by treatment. Grey rectangle indicates the upper limit of sampling, and the establishment year (1957) of the study.

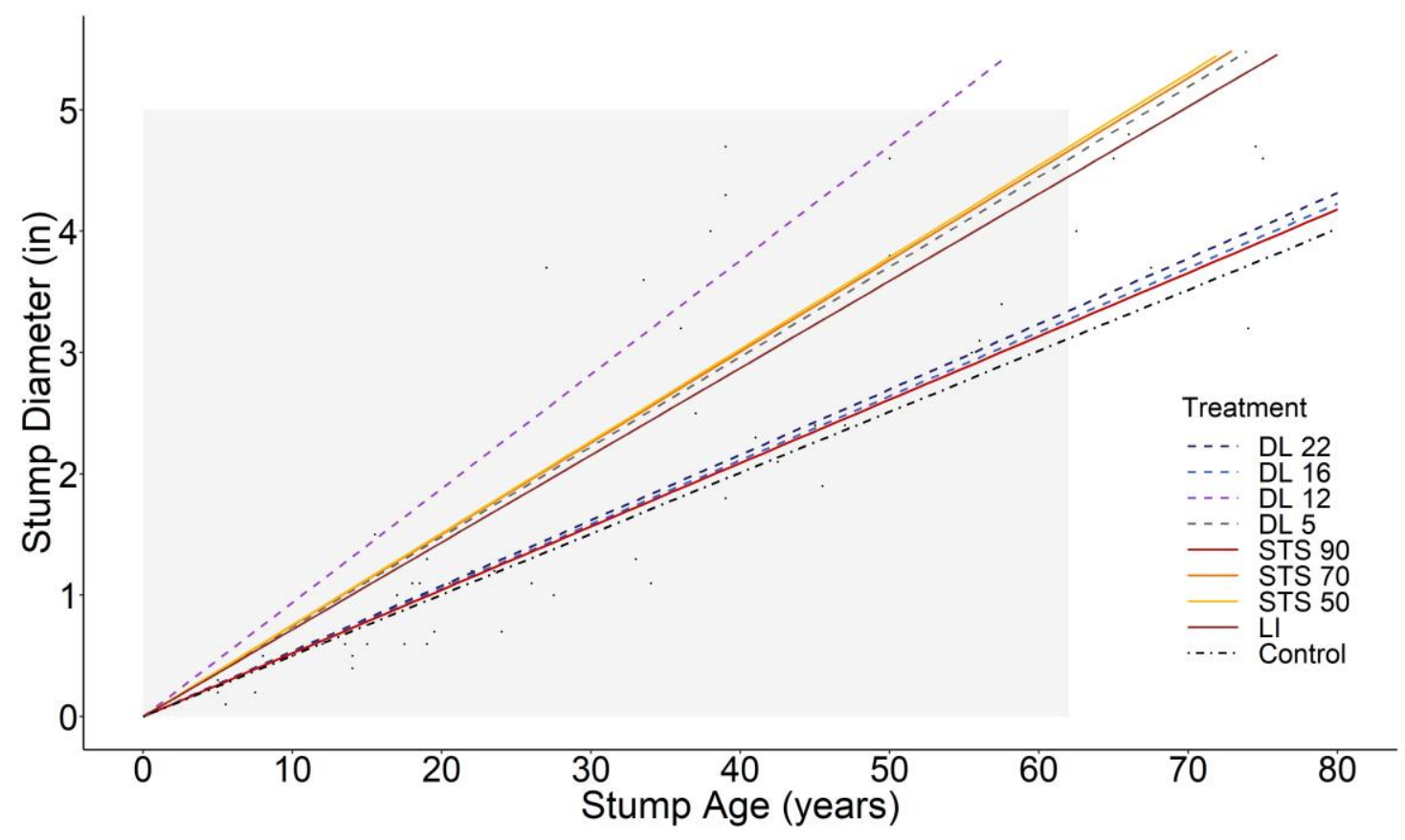

Figure 3-9 Relationship between stump height annual ring count (years) and diameter at stump height (in) for sugar maple regeneration $(\mathrm{n}=55)>1 \mathrm{ft}$ tall and $<5$ in dbh by treatment. Grey rectangle indicates the upper limit of sampling, and the establishment year (1957) of the study. 


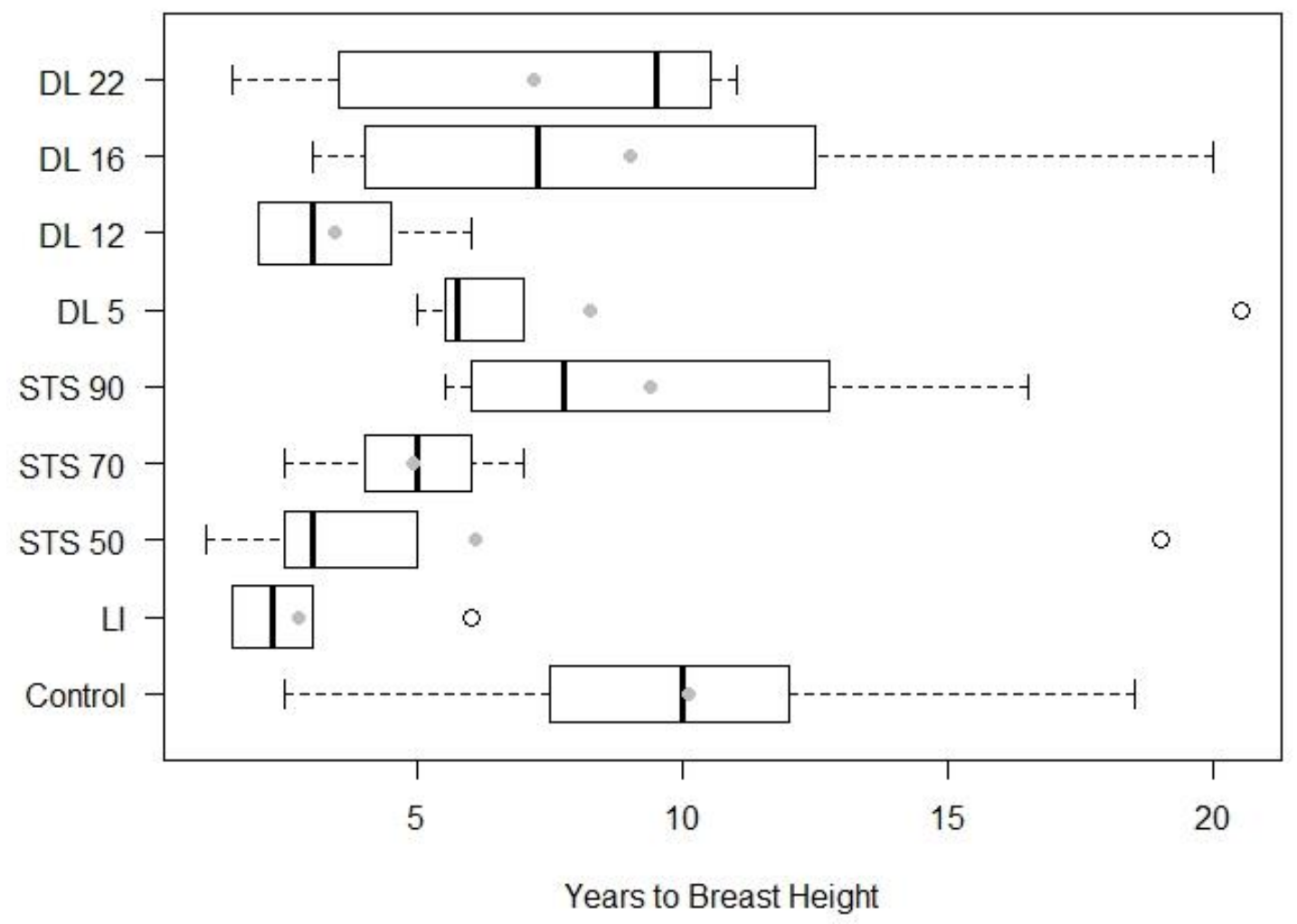

Figure 3-10 Boxplots of years to breast height for sugar maple regeneration by treatment. Solid grey dot indicates mean.

Table 3-3 Summary table for breast height diameter-age regression and years to breast height boxplots for sugar maple regeneration by treatment.

\begin{tabular}{cccccc}
\hline Treatment & Equation & $r^{2}$ & $\begin{array}{c}\text { Sample } \\
\text { Size }\end{array}$ & $\begin{array}{c}\text { Median Years to } \\
\text { Breast Height }\end{array}$ & $\begin{array}{c}\text { Estimated Age } \\
\text { at 5-in dbh }\end{array}$ \\
\hline $\mathrm{DL} \mathrm{22}$ & $\mathrm{DBH}=0.0574{ }^{*} \mathrm{Age}_{\mathrm{BH}}$ & 0.98 & 5 & 9.5 & 87 \\
$\mathrm{DL} \mathrm{16}$ & $\mathrm{DBH}=0.0570{ }^{*} \mathrm{Age}_{\mathrm{BH}}$ & 0.99 & 6 & 7.3 & 88 \\
$\mathrm{DL} \mathrm{12}$ & $\mathrm{DBH}=0.0951{ }^{*} \mathrm{Age}_{\mathrm{BH}}$ & 0.93 & 6 & 3.0 & 53 \\
$\mathrm{DL} \mathrm{5}$ & $\mathrm{DBH}=0.0875{ }^{*} \mathrm{Age}_{\mathrm{BH}}$ & 0.93 & 6 & 5.8 & 57 \\
STS 90 & $\mathrm{DBH}=0.0615{ }^{*} \mathrm{Age}_{\mathrm{BH}}$ & 0.98 & 5 & 7.8 & 81 \\
STS 70 & $\mathrm{DBH}=0.0662{ }^{*} \mathrm{Age}_{\mathrm{BH}}$ & 0.82 & 5 & 5.0 & 76 \\
STS 50 & $\mathrm{DBH}=0.0702{ }^{*} \mathrm{Age}_{\mathrm{BH}}$ & 0.86 & 5 & 3.0 & 71 \\
$\mathrm{LI}$ & $\mathrm{DBH}=0.0648{ }^{*} \mathrm{Age}_{\mathrm{BH}}$ & 0.98 & 6 & 2.3 & 77 \\
Control & $\mathrm{DBH}=0.0505{ }^{*} \mathrm{Age}_{\mathrm{BH}}$ & 0.86 & 5 & 10.0 & 99 \\
\hline
\end{tabular}




\section{Discussion}

Understanding the dynamics of the regeneration layer in response to long-term management is crucial for assessing the efficacy and sustainability of different silvicultural methods (Tubbs 1977b, Ashton and Kelty 2018). The relationship found between regeneration densities and overstory basal area (Figure 3-1) was not unexpected as the positive relationship between seedling densities and high basal areas (Kern et al. 2013, Danyagri et al. 2019), that is attenuated in larger size classes (Henry et al. 2021) has been previously reported in northern hardwoods. Higher overstory basal area does lead to more seedlings, but between treatments there has been very little variation in sapling densities. A possible explanation of this is that within high basal area treatments there are also higher rates of mortality due to increased levels of competition (Oliver and Larson 1996). Additionally, all treatment overstories have high relative abundances of sugar maple (Draper and Froese in press) which generally have a greater capacity to produce seed as they mature (Garrett and Graber 1995). This paired with the tolerant silvics of sugar maple (Burns and Honkala 1990, Willis et al. 2016), suggests that there is a species-specific relationship between regeneration and overstory densities that is not surprising (Caspersen and Saprunoff 2005, Graignic et al. 2014, Henry et al. 2021).

Notably, when examining species composition, sugar maple dominance in the understory does not follow the same patterns as those exhibited in the overstory. In contrast to previous conclusions of Bodine (2000), Campione et al. (2012), and Previant (2015), sugar maple dominance in the understory has decreased not only in the larger size classes but also between the last three harvests (Figures 3-2, 3-3, 3-4). This shift towards higher species diversity, however small, may be an indication that ecological lags are still occurring in 
these forest systems. Alongside sugar maple, black cherry can also survive under dense canopies waiting for canopy gaps (Closset-Kopp et al. 2007). Indeed, black cherry has become more prominent in the understory, even surpassing hophornbeam densities in the LI and control. Even with the decline of sugar maple dominance in all treatments, there is a slight difference between overall species diversity between the types of treatments. As literature suggests, the DL treatments should have higher species richness than the STS treatments (Table 3-1), as more intense harvests create and maintain regeneration opportunities for species that have lesser tolerance than sugar maple (Caspersen and Saprunoff 2005, Webster et al. 2018, Danyagri et al. 2019).

Longer return intervals have also affected the understory upgrowth and recruitment in the high intensity treatments. The DL 12 and 5, modeled after historic commercial highgrading and clear-cutting (Eyre and Zillgitt 1950), although not recommended as long-term management methods (Erickson et al. 1990), serve to provide contrast to the other treatments in the study. In these two treatments, the large proportion of basal area harvested has led to depressed seedling densities by proxy of reducing mature seed trees and has increased the cover of herbaceous and weedy species (Campione et al. 2012). Comparatively, the control and STS treatments show more even regeneration structure across these harvest entries. It is surprising how similar the structures are between these six treatments.

The regression analysis on the sugar maple seedlings and saplings shows positive age-size relationships in every treatment. As reported in Tubbs (1977a), Kenefic and Nyland (1999), Macmillan and Aarssen (2017), these data refute the conclusion of Previant (2015). 
Overall, the sampled trees had a tighter relationship in the smaller size classes, and older saplings have been found to have wider variances of diameter (Macmillan and Aarssen 2017). In addition, size specific recruitment rates can be compared between the nine treatments. It is not surprising that the control would have the slowest growth/recruitment rate and the high intensity treatments would have the fastest rates (Figure 3-8), as seedling growth rates decrease with an increase of canopy density (Tubbs 1968, Tubbs 1977c, Godman et al. 1990). However, the regressions in Figure 3-8 only represent the growth and recruitment after the trees have surpassed breast height. The low recruitment such as in the DL 16 and control could suggest that there is a higher chance of mortality for the sugar maple regeneration (Petritan et al. 2007). Nevertheless, the potentially significant sampling errors from deriving age and attributes like years to breast height could be masking anomalous data.

Despite the small sample sizes, the age structures across the treatments were as expected. Although, in the boxplots (Figure 3-10), the range of data also increases in treatments with higher basal area. This suggests that in low intensity treatments, some trees are able to quickly capture canopy gaps within a decade, while others can stay suppressed in the understory, growing very slow. Measuring the microsite factors (i.e. light, soil resources, proximity to canopy gaps) throughout a growing season could help address the differences in understory mortality and recruitment.

In terms of assessing the sustainability of decadal regeneration levels, critical judgements can only be made about the selection treatments. The selection treatments at the Cutting Methods Study can be compared using these different stocking guides because selection 
systems utilize thinning to create regeneration, resulting in an undefined rotation. However, the diameter-limits cannot be tested using these guides as they are not a silviculture system, and only are defined as a method of releasing lower crown classes by removing dominant trees (Nyland 2016, Ashton and Kelty 2018).

The sustainability of the overstory depends on sufficient ingrowth to match harvest removals; however, it is difficult to accurately evaluate regeneration stocking in the understory. The regeneration stocking guides of Nyland (1998) and Tubbs (1977c), based on Eyre and Zillgitt (1953), were developed to evaluate understory stocking under the selection system in the Lake States. The problem is, the recommended stocking of 202 stems $\mathrm{ac}^{-1}$ only covers the 2-4-inch dbh class (Eyre and Zillgitt 1953). For this comparison, the stem density of the 3-5-inch dbh class and half of the 1-3-inch dbh class is used as an approximate size class. In 1998, only the STS 90 had met this stocking. In 2008, all the selection treatments had below $200 \mathrm{stems} \mathrm{ac}^{-1}$; and as of 2020 all selection treatments met the stocking level. Other than the recommendations of Eyre and Zillgitt (1953), the Michigan DNR in 2015 published the Silvics and Management Guidance Manual which describes several different levels of regeneration stocking based on height class. Minimum stocking of 'acceptable' species greater than $6 \mathrm{ft}$ tall, 15-years after harvest must be 150 stems $\mathrm{ac}^{-1}$ while target stocking is $300 \mathrm{stems} \mathrm{ac}^{-1}$. Additionally, regeneration surveys taken 4-6 years after harvest in canopy gaps must met a minimum of $2000 \mathrm{stems} \mathrm{ac}^{-1}$ greater than $1 \mathrm{ft}$ tall and of 'desirable' species (MI DNR 2015). Using the regeneration survey stocking levels, only the 2008 STS 90 regeneration density did not meet the minimum stocking. It is critical to understand that these standards that historically maintained well-stocked regenerating all-aged northern hardwood forests may reflect historical context. 
In the current sphere of management, the combination of natural system complexities and anthropogenic pressures, creates a new paradox between self-organizing and managementdependent 'natural' systems. Blum (1975) described this well, "For the most part, our forests today are the manifestation of ecological responses to past perturbations by man that were probably logical in the context of the times." Even now, forest managers are adapting management plans in response to ecological lags due to what may have seemed like an inconsequential decision in the past. As more unconventional silviculture methods continue to be implemented, not only is it necessary to test these against current and future attainable goals, but it is also crucial to pay attention to the dynamics that emerge in response to these methods. 


\section{Conclusion}

Overall, these results support the notion that regeneration in forests with similar disturbance regimes (Frelich and Lorimer 1985, Henry et al. 2021) and management applications (Klopcic and Boncina 2012, Kern et al. 2014) will respond in a predictable and desirable manner. After 62-years of consistent management, all treatments with the exception of the DL 5, had similar sapling densities as overstory basal area has little effect on this size class. Even though species diversity was higher in the high intensity treatments, the regeneration densities had more variability between the past three harvest cycles as compared to the medium and low intensity treatments. Despite these differences, all treatments have a positive age-size relationship in the regeneration and have regenerated and recruited new age classes since 1957. These results suggest that northern hardwood management methods, beyond the recommendations of Arbogast (1957), can be sustainable under current regeneration stocking guides. Nevertheless, caution should be taken with the application of these methods, as differences in disturbance regimes (past and present), management application, and ungulate herbivory pressure (Frelich and Lorimer 1985, Henry et al. 2021), may result in undesirable outcomes (Klopcic and Boncina 2012, Kern et al. 2014). Furthermore, the shifting species compositions of the understory could suggest either the presence of ecological lags or dynamic shifts due to climate change (D'Amato et al. 2011, Royo et al. 2021). As the repercussions of climate change will continue to affect northern hardwoods, the continual maintenance and monitoring of the Cutting Methods Study and other long-term studies are crucial for adaptive mitigation management as opposed to forest rehabilitation. 


\section{Literature Cited}

Angers, V. A., C. Messier, M. Beaudet, and A. Leduc. 2005. Comparing composition and structure in old-growth and harvested (selection and diameter-limit cuts) northern hardwood stands in Quebec. Forest Ecology and Management 217:275-293.

Arbogast, C. 1953. Managing northern hardwoods in the Lake States. LS-23, USDA Forest Service, Lake States Forest Experiment Station, St. Paul, MN.

Arbogast, C. J. 1957. Marking guides for northern hardwoods under the selection system. LS-56, USDA Forest Service, Lake States Forest Experiment Station, St. Paul, MN.

Ashton, M. S., and M. J. Kelty. 2018. The practice of silviculture: applied forest ecology. John Wiley \& Sons.

Avery, T. E., and H. E. Burkhart. 2002. Forest Measurements. 5th edition. McGraw-Hill, New York, New York.

Bassil, S., R. D. Nyland, C. C. Kern, and L. S. Kenefic. 2019. Dynamics of the diameter distribution after selection cutting in uneven-and even-aged northern hardwood stands: a long-term evaluation. Canadian Journal of Forest Research 49:15251539.

Berndt, L. W. 1988. Soil survey of Baraga County Area, Michigan. US Soil Conservation Service, Washington, D.C.

Blum, B. M. 1975. Regeneration and uneven-aged silviculture--the state of the art. Pages 63-83 in Uneven-aged Silviculture and Management in the Eastern United States In-Service Workshop. Timber Management Research, Forest Service, U.S. Department of Agriculture, Morgantown, West Virginia. 
Bodine, J. T. 2000. The effects of eight silvicultural treatments on quality development, financial returns, and regeneration following 42 years of management in secondgrowth, northern hardwood stands. Thesis. Michigan Technological University.

Bourdo, E. A. 1957. Plan for the establishment of 1956 stocking level management studies in "selectively cut" northern hardwoods and a brief outline of associated terminal studies. Michigan Technological University, L'Anse, Michigan.

Burns, R. M., and B. H. Honkala. 1990. Silvics of North America: Volume 2. Hardwoods. 654, USDA Forest Service.

Campione, M. A., L. M. Nagel, and C. R. Webster. 2012. Herbaceous-layer community dynamics along a harvest-intensity gradient after 50 years of consistent management. Open Journal of Forestry 2:97-109.

Caspersen, J. P., and M. Saprunoff. 2005. Seedling recruitment in a northern temperate forest: the relative importance of supply and establishment limitation. Canadian Journal of Forest Research 35:978-989.

Closset-Kopp, D., O. Chabrerie, B. Valentin, H. Delachapelle, and G. Decocq. 2007. When Oskar meets Alice: Does a lack of trade-off in r/K-strategies make Prunus serotina a successful invader of European forests? Forest Ecology and Management 247:120-130.

Crow, T. R., D. S. Buckley, E. A. Nauertz, and J. C. Zasada. 2002. Effects of management on the composition and structure of northern hardwood forests in Upper Michigan. Forest Science 48:129-145.

Cybis Elektronik \& Data AB. 2018. CooRecorder 9.5. Saltsjöbaden, Sweden. 
D’Amato, A. W., J. B. Bradford, S. Fraver, and B. J. Palik. 2011. Forest management for mitigation and adaptation to climate change: Insights from long-term silviculture experiments. Forest Ecology and Management 262:803-816.

Danyagri, G., S. K. Baral, and G. Pelletier. 2019. Effects of disturbance and site factors on sapling dynamics and species diversity in northern hardwood stands. Forest Ecology and Management 444:225-234.

Draper, M. C. 2021. Evaluating long-term growth and yield in upper Great Lakes region northern hardwoods cutting trials. Thesis. Michigan Technological University.

Draper, M. C., and R. E. Froese. in press. Six decades of growth and yield and financial return in a silviculture experiment in northern hardwoods. Forest Science.

Erdmann, G. G., and R. R. Oberg. 1973. Fifteen-year results from six cutting methods in second-growth northern hardwoods. NC-100, USDA Forest Service, North Central Forest Experiment Station, St. Paul, MN.

Erickson, M. D., D. D. Reed, and G. D. Mroz. 1990. Stand development and economic analysis of alternative cutting methods in northern hardwoods: 32-year results. Northern Journal of Applied Forestry 7:153-158.

Eyre, F. H., and W. M. Zillgitt. 1950. Size-class distribution in old-growth northern hardwoods twenty years after cutting. LS-21, USDA Forest Service, Lake States Forest Experiment Station, St. Paul, MN.

Eyre, F. H., and W. M. Zillgitt. 1953. Partial cuttings in northern hardwoods of the Lake States: twenty-year experimental results. LS-1076, USDA Forest Service, Lake States Forest Experiment Station, Broomall, PA. 
Fisichelli, N. A., L. E. Frelich, and P. B. Reich. 2014. Temperate tree expansion into adjacent boreal forest patches facilitated by warmer temperatures. Ecography 37:152-161.

Frelich, L. E., and C. G. Lorimer. 1985. Current and predicted long-term effects of deer browsing in hemlock forests in Michigan, USA. Biological Conservation 34:99120.

Garrett, P. W., and R. E. Graber. 1995. Sugar maple seed production in northern New Hampshire. NE-697, USDA Forest Service, Northeastern Forest Experiment Station, Radnor, PA.

Godman, R. M., H. W. Yawney, and C. H. Tubbs. 1990. Silvics of North America Volume 2: Hardwoods. 654, USDA Forest Service.

Goodburn, J. M., and C. G. Lorimer. 1999. Population structure in old-growth and managed northern hardwoods: an examination of the balanced diameter distribution concept. Forest Ecology and Management 118:11-29.

Grabowski, M. 2019. Dutch elm disease. University of Minnesota, University of Minnesota Extention. https://extension.umn.edu/plant-diseases/dutch-elm-disease

Graignic, N., F. Tremblay, and Y. Bergeron. 2014. Geographical variation in reproductive capacity of sugar maple (Acer saccharum Marshall) northern peripheral populations. Journal of Biogeography 41:145-157.

Henry, C. R., M. B. Walters, A. O. Finley, G. J. Roloff, and E. J. Farinosi. 2021. Complex drivers of sugar maple (Acer saccharum) regeneration reveal challenges to long-term sustainability of managed northern hardwood forests. Forest Ecology and Management 479:118541. 
Kenefic, L. S., and C. C. Kern. 2015. Early northern hardwood silvicultural research at the Dukes Experimental Forest, Michigan. Journal of Forestry 113:258-261.

Kenefic, L. S., and R. D. Nyland. 1999. Sugar maple height-diameter and age-diameter relationships in an uneven-aged northern hardwood stand. Northern Journal of Applied Forestry 16:43-47.

Kern, C., G. Erdmann, L. Kenefic, B. Palik, and T. Strong. 2014. Development of the selection system in northern hardwood forests of the Lake States: an 80-year silviculture research legacy. Pages 201-223 USDA Forest Service Experimental Forests and Ranges. Springer.

Kern, C. C., A. W. D'Amato, and T. F. Strong. 2013. Diversifying the composition and structure of managed late-successional forests with harvest gaps: What is the optimal gap size? Forest Ecology and Management 304:110120.

Klopcic, M., and A. Boncina. 2012. Recruitment of tree species in mixed selection and irregular shelterwood forest stands. Annals of Forest Science 69:915-925.

Kozac, A., and R. A. Kozac. 1995. Notes on regression through the origin. The Forestry Chronicle 71:326-330.

Lawrimore, J. H., R. Ray, S. Applequist, B. Korzeniewski, and M. J. Menne. 2016. Global Summary of the Year (1980-2019), Version 1. NOAA National Centers for Environmental Information. https://doi.org/10.7289/JWPF-Y430

Leak, W. B., and P. E. Sendak. 2002. Field note—changes in species, grade, and structure over 48 years in a managed New England northern hardwood stand. Northern Journal of Applied Forestry 19:25-28. 
Macmillan, J., and L. W. Aarssen. 2017. Recruitment success for mast year cohorts of sugar maple (Acer saccharum) over three decades of heavy deer browsing. The American Midland Naturalist 178:36-46.

Metzger, F. T., and C. H. Tubbs. 1971. The influence of cutting method on regeneration of second-growth northern hardwoods. Journal of Forestry 69:559-564.

MI DNR. 2015. Silvics and management guidance manual. IC4111, Michigan Department of Natural Resources, Forest Resources and Wildlife Division, Lansing, Michigan.

Neuendorff, J. K., L. M. Nagel, C. R. Webster, and M. K. Janowiak. 2007. Stand structure and composition in a northern hardwood forest after 40 years of singletree selection. Northern Journal of Applied Forestry 24:197-202.

Niese, J. N., and T. F. Strong. 1992. Economic and tree diversity trade-offs in managed northern hardwoods. Canadian Journal of Forest Research 22:1807-1813.

Niese, J. N., T. F. Strong, and G. G. Erdmann. 1995. Forty years of alternative management practices in second-growth, pole-size northern hardwoods. II. Economic evaluation. Canadian Journal of Forest Research 25:1180-1188.

Nyland, R. D. 1998. Selection system in northern hardwoods. Journal of Forestry 96:1821.

Nyland, R. D. 2016. Silviculture: concepts and applications. Waveland Press.

Oksanen, J., F. G. Blanchet, M. Friendly, R. Kindt, P. Legendre, D. McGlinn, P. R. Minchin, R. B. O'Hara, G. L. Simpson, P. Solymos, M. H. H. Stevens, E. Szoecs, and H. Wagner. 2020. vegan: Community Ecology Package. https://CRAN.Rproject.org/package=vegan 
Oliver, C. D., and B. A. Larson. 1996. Forest Stand Dynamics, Update Edition. School of Forestry and Environmental Studies, Yale University.

Petritan, A. M., B. Von Lupke, and I. C. Petritan. 2007. Effects of shade on growth and mortality of maple (Acer pseudoplatanus), ash (Fraxinus excelsior) and beech (Fagus sylvatica) saplings. Forestry: An International Journal of Forest Research 80:397-412.

Pond, N. C., R. E. Froese, and L. M. Nagel. 2014. Sustainability of the selection system in northern hardwood forests. Forest Science 60:374-381.

Previant, W. 2015. Legacy and opportunity in northern hardwood forests. Dissertation. Michigan Technological University.

R Core Team. 2019. R: A language and environment for statistical computing. $R$ Foundation for Statistical Computing, Vienna, Austria. https://www.R-project.org

Reed, D. D., M. J. Holmes, and J. A. Johnson. 1986. A 22-year study of stand development and financial return in northern hardwoods. Northern Journal of Applied Forestry 3:35-38.

Reed, D. D., and G. D. Mroz. 1997. Resource assessment in forested landscapes. John Wiley \& Sons.

Royo, A. A., L. A. Vickers, R. P. Long, T. E. Ristau, S. H. Stoleson, and S. L. Stout. 2021. The forest of unintended consequences: anthropogenic actions trigger the rise and fall of black cherry. BioScience 71:683-696.

SAF. 2018. The Dictionary of Forestry. Society of American Foresters. 
Stoeckeler, J. H. 1955. Establishment report for cutting methods study (A-3) in pulpwood sized northern hardwoods., USDA Forest Service, Lake States Forest Experimental Station, St. Paul, MN.

Strong, T. F. 1999. Productivity of even-aged, second-growth northern hardwoods brought under uneven-aged management. Page 7 Improving Forest Productivity for Timber: A Key to Sustainability, Duluth, MN.

Strong, T. F., G. G. Erdmann, and J. N. Niesse. 1995. Forty years of alternative management practices in second-growth, pole-size northern hardwoods: tree quality development. Canadian Journal of Forest Research 25:1173-1179.

Tubbs, C. H. 1968. The influence of residual stand densities on regeneration in sugar maple stands. NC-47, USDA Forest Service, North Central Forest Experimental Station, St. Paul, MN.

Tubbs, C. H. 1977a. Age and structure of a northern hardwood selection forest, 19291976. Journal of Forestry 75:22-24.

Tubbs, C. H. 1977b. Manager's handbook for northern hardwoods in the North-Central States. NC-39, USDA Forest Service, North Central Forest Experimental Station, St. Paul, MN.

Tubbs, C. H. 1977c. Natural regeneration of northern hardwoods in the northern Great Lakes region. NC-150, USDA Forest Service, North Central Forest Experimental Station, St. Paul, MN.

Walters, M. B., G. J. Roloff, C. R. Henry, J. P. Hartman, M. L. Donovan, E. J. Farinosi, and M. D. Starking. 2020. Rethinking northern hardwood forest management 
paradigms with silvicultural systems research: research-management partnerships ensure relevance and application. Journal of Forestry 118:260-274.

Webster, C. R., Y. L. Dickinson, J. I. Burton, L. E. Frelich, M. A. Jenkins, C. C. Kern, P. Raymond, M. R. Saunders, M. B. Walters, and J. L. Willis. 2018. Promoting and maintaining diversity in contemporary hardwood forests: Confronting contemporary drivers of change and the loss of ecological memory. Forest Ecology and Management 421:98-108.

Wickham, H. 2016. ggplot2: Elegant Graphics for Data Analysis. Springer-Verlag New York. https://ggplot2.tidyverse.org

Willis, J. L., M. B. Walters, and E. Farinosi. 2016. Local seed source availability limits young seedling populations for some species more than other factors in northern hardwood forests. Forest Science 62:440-448. 


\section{Supplementary Data}

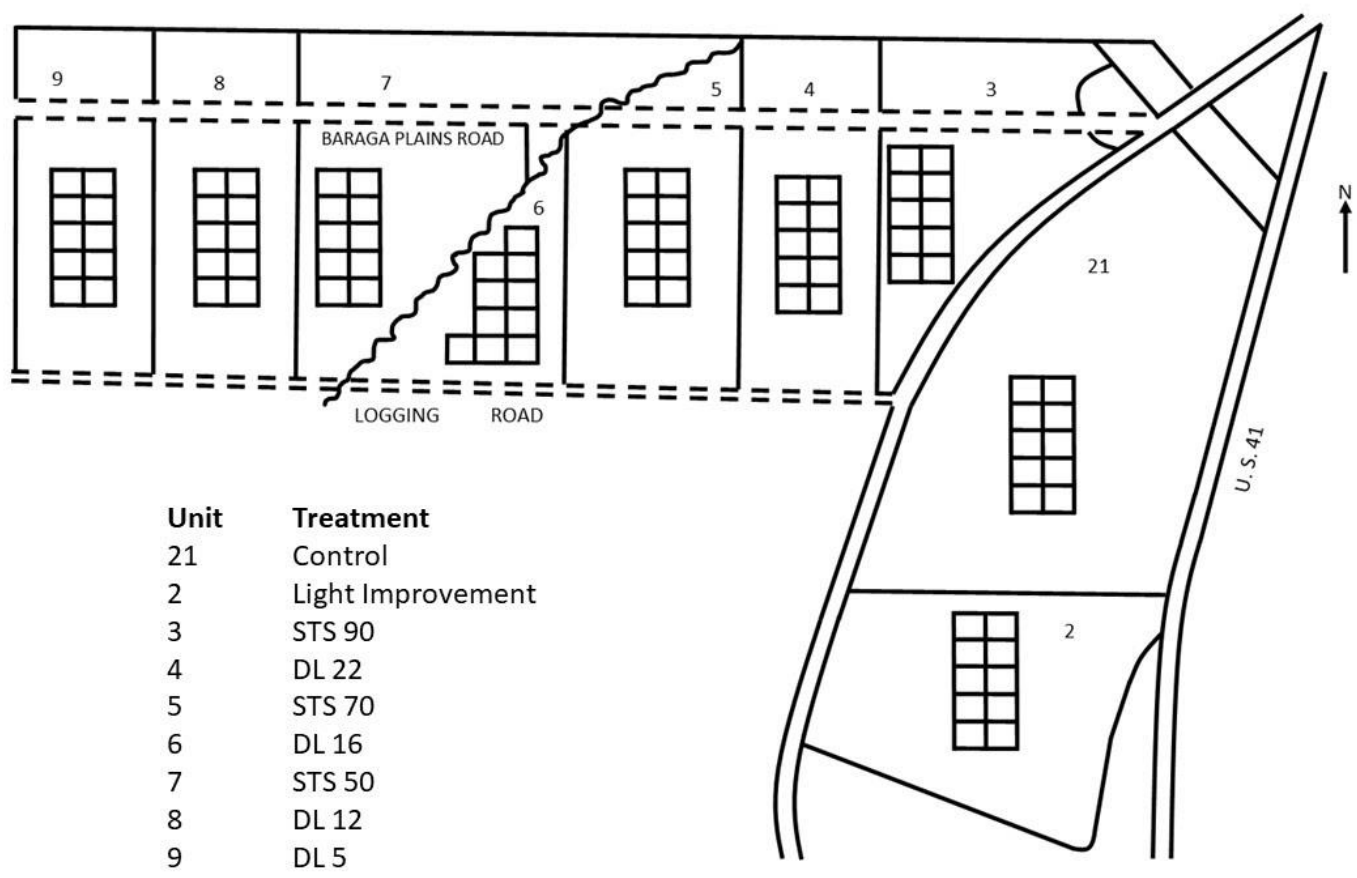

Figure 7-1 Diagram of Cutting Methods Study, Alberta, Michigan. Adapted from (Bourdo 1957). 


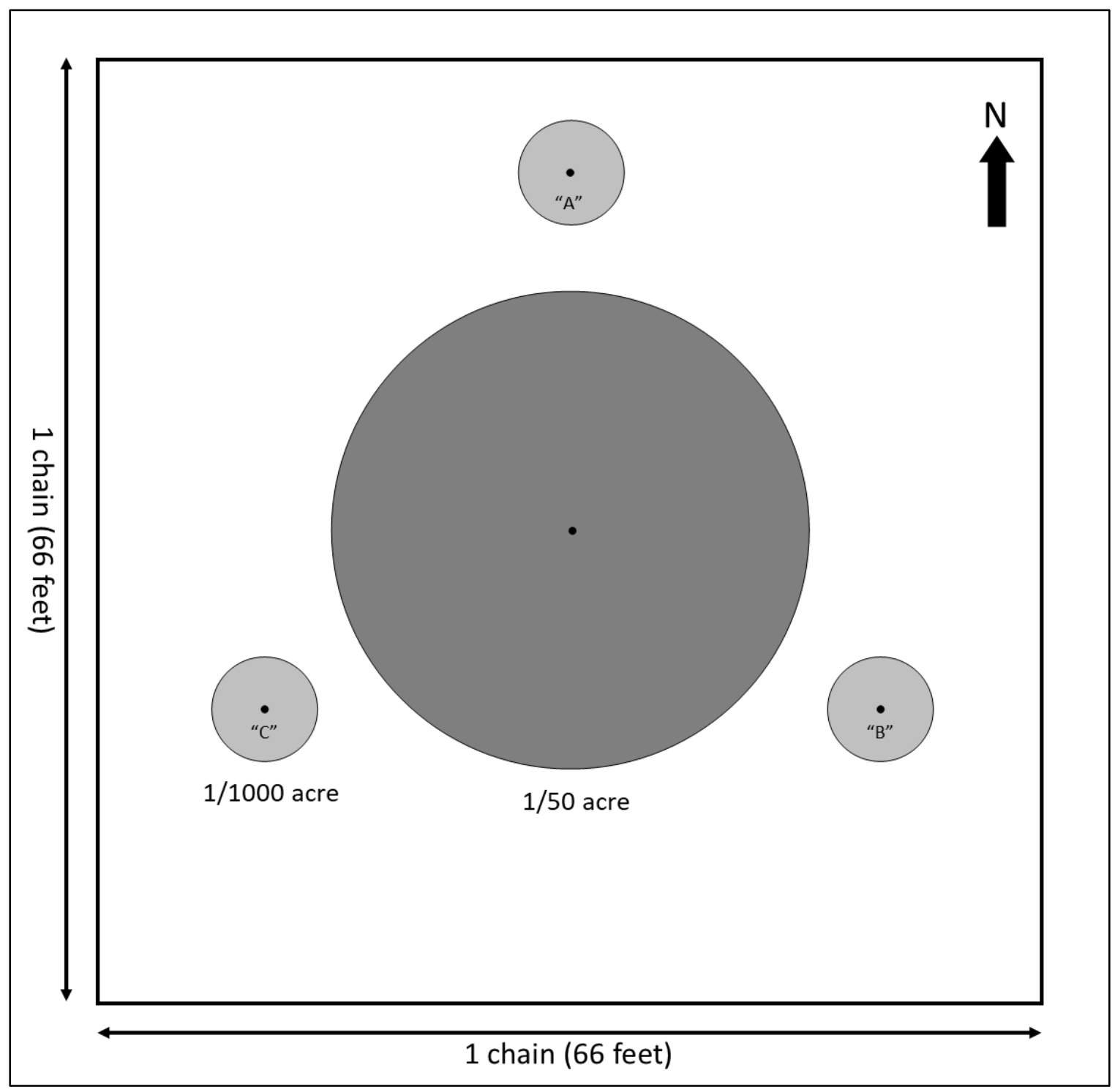

Figure 7-2 Diagram of sample design for regeneration plots within 1/10-acre subplots. Digitized and adapted from Bodine (2000). Plot radius of $1 / 50$-acre is 16.7 feet and radius of $1 / 1000$-acre is 3.7 feet. 
Table 7-1 Pre- and post-harvest basal area $\left(\mathrm{ft}^{2} \mathrm{ac}^{-1}\right)$ and harvested proportion for 1998 , 2008, and 2018 harvest entries.

\begin{tabular}{|c|c|c|c|c|c|c|c|c|c|c|}
\hline \multicolumn{2}{|c|}{ Entry Year } & DL 22 & DL 16 & DL 12 & $\mathrm{DL} 5$ & STS 90 & STS 70 & STS 50 & $\mathrm{LI}$ & Control \\
\hline \multirow{2}{*}{1998} & $\mathrm{BA}_{\mathrm{a}}$ & 120 & 90 & 70 & 90 & 110 & 100 & 80 & 90 & 140 \\
\hline & $\mathrm{BA}_{\mathrm{b}}$ & 110 & 70 & 70 & 0 & 90 & 70 & 50 & 80 & 140 \\
\hline \multicolumn{2}{|c|}{ Harvest Percent } & $8 \%$ & $22 \%$ & $0 \%$ & $100 \%$ & $18 \%$ & $30 \%$ & $38 \%$ & $11 \%$ & $0 \%$ \\
\hline \multirow{2}{*}{2008} & $\mathrm{BA}_{\mathrm{a}}$ & 100 & 90 & 90 & 10 & 90 & 80 & 70 & 90 & 140 \\
\hline & $\mathrm{BA}_{\mathrm{b}}$ & 100 & 80 & 40 & 10 & 80 & 70 & 50 & 70 & 140 \\
\hline \multicolumn{2}{|c|}{ Harvest Percent } & $0 \%$ & $11 \%$ & $56 \%$ & $0 \%$ & $11 \%$ & $12 \%$ & $29 \%$ & $22 \%$ & $0 \%$ \\
\hline \multirow{2}{*}{2018} & $\mathrm{BA}_{\mathrm{a}}$ & 120 & 100 & 70 & 30 & 90 & 90 & 60 & 80 & 140 \\
\hline & $\mathrm{BA}_{\mathrm{b}}$ & 100 & 70 & 40 & 30 & 90 & 70 & 50 & 70 & 140 \\
\hline \multicolumn{2}{|c|}{ Harvest Percent } & $17 \%$ & $30 \%$ & $43 \%$ & $0 \%$ & $0 \%$ & $22 \%$ & $16 \%$ & $13 \%$ & $0 \%$ \\
\hline
\end{tabular}

Table 7-2 Pre-harvest basal area $\left(\mathrm{ft}^{2} \mathrm{ac}^{-1}\right)$ of live trees $>12$ in $\mathrm{dbh}$ for the 1998, 2008, and 2018 harvest entries. These data accompany those presented in Figure 3-1.

\begin{tabular}{cccccccccc}
\hline & DL 22 & DL 16 & DL 12 & DL 5 & STS 90 & STS 70 & STS 50 & LI & Control \\
\hline 1998 & 94 & 56 & 24 & 18 & 91 & 75 & 55 & 71 & 121 \\
2008 & 87 & 48 & 41 & 0 & 65 & 59 & 43 & 69 & 135 \\
2018 & 94 & 58 & 14 & 0 & 74 & 71 & 45 & 66 & 140 \\
\hline
\end{tabular}

Table 7-3 Regression equations and coefficients of determination for the relationship between pre-harvest basal area in trees greater than 12 in dbh and regeneration densities across all treatments in each size class for the past three harvest entries.

\begin{tabular}{lcccccc}
\hline \multicolumn{1}{c}{ Size Class } & Equation & $\mathbf{r}^{2}$ & Equation & $\mathbf{r}^{2}$ & Equation & $\mathbf{r}^{\mathbf{2}}$ \\
\hline$<1^{\prime}$ tall & $1009.1 \mathrm{x}+23811$ & 0.644 & $282.6 \mathrm{x}-2243$ & 0.636 & $3605.4 \mathrm{x}+41150$ & 0.644 \\
1-3' tall & $53.4 \mathrm{x}+2509.6$ & 0.268 & $34.1 \mathrm{x}+1494.6$ & 0.075 & $29.3 \mathrm{x}+775.2$ & 0.588 \\
$>3^{\prime}$ tall, $<1 "$ dbh & $-7.4 \mathrm{x}+1576.9$ & 0.109 & $1.8 \mathrm{x}+1318.7$ & 0.004 & $10.8 \mathrm{x}+769.6$ & 0.299 \\
1-3" dbh & $-0.4 \mathrm{x}+239.1$ & 0.024 & $-0.4 \mathrm{x}+272.8$ & 0.015 & $-2.4 \mathrm{x}+497.1$ & 0.726 \\
3-5" dbh & $-0.7 \mathrm{x}+113.1$ & 0.614 & $-0.3 \mathrm{x}+60.3$ & 0.537 & $-0.1 \mathrm{x}+63.2$ & 0.100 \\
\hline
\end{tabular}




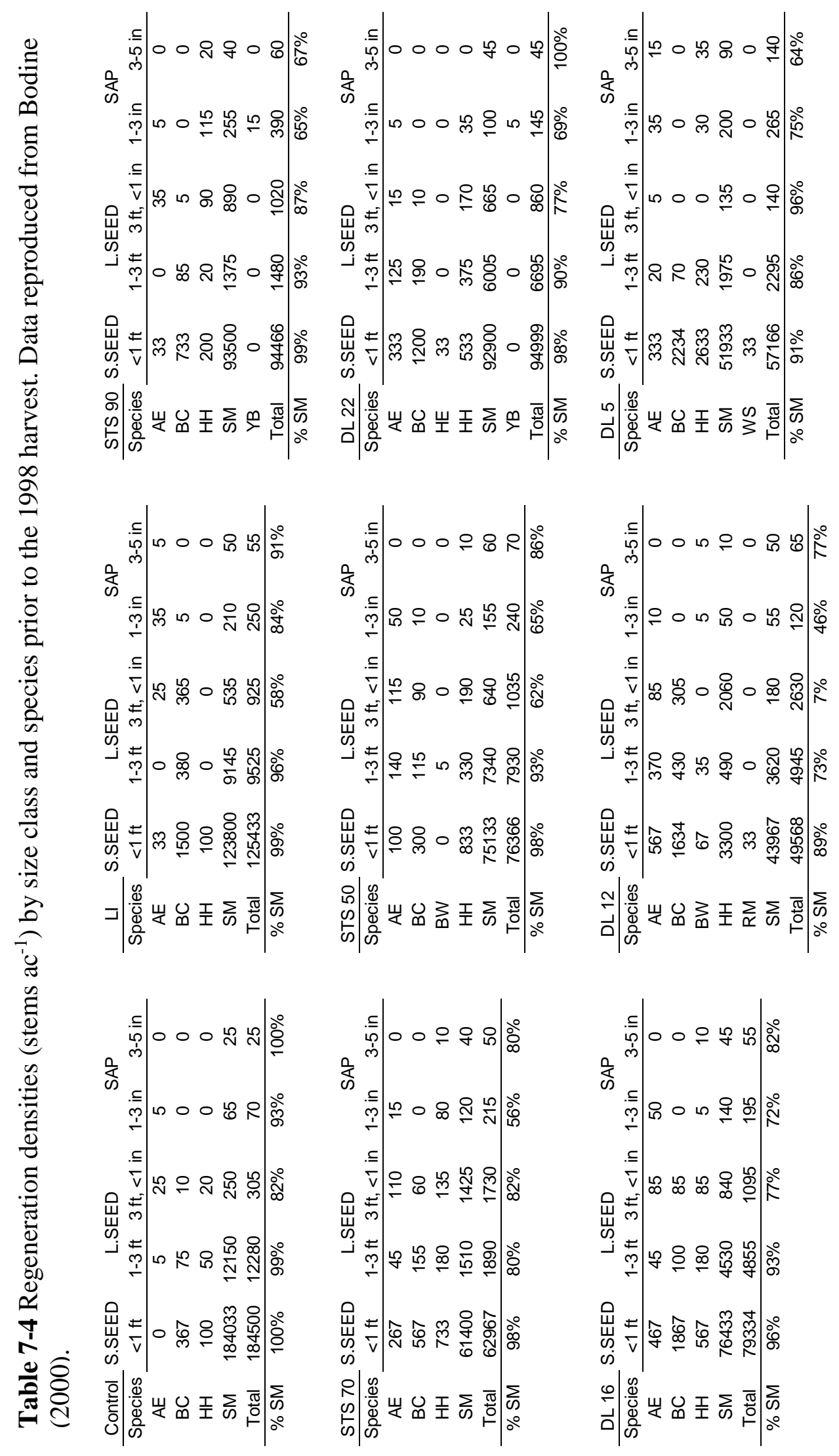




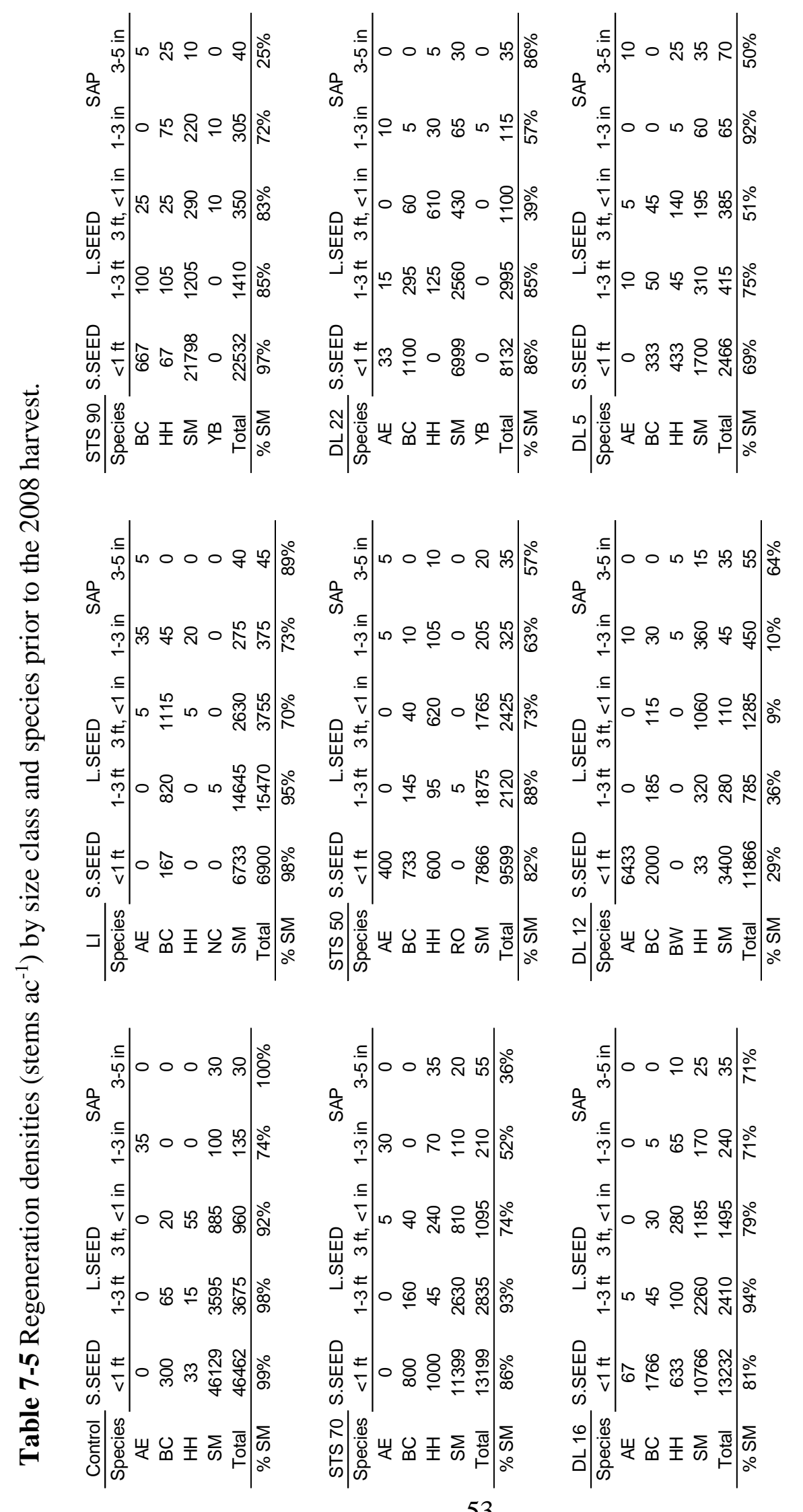




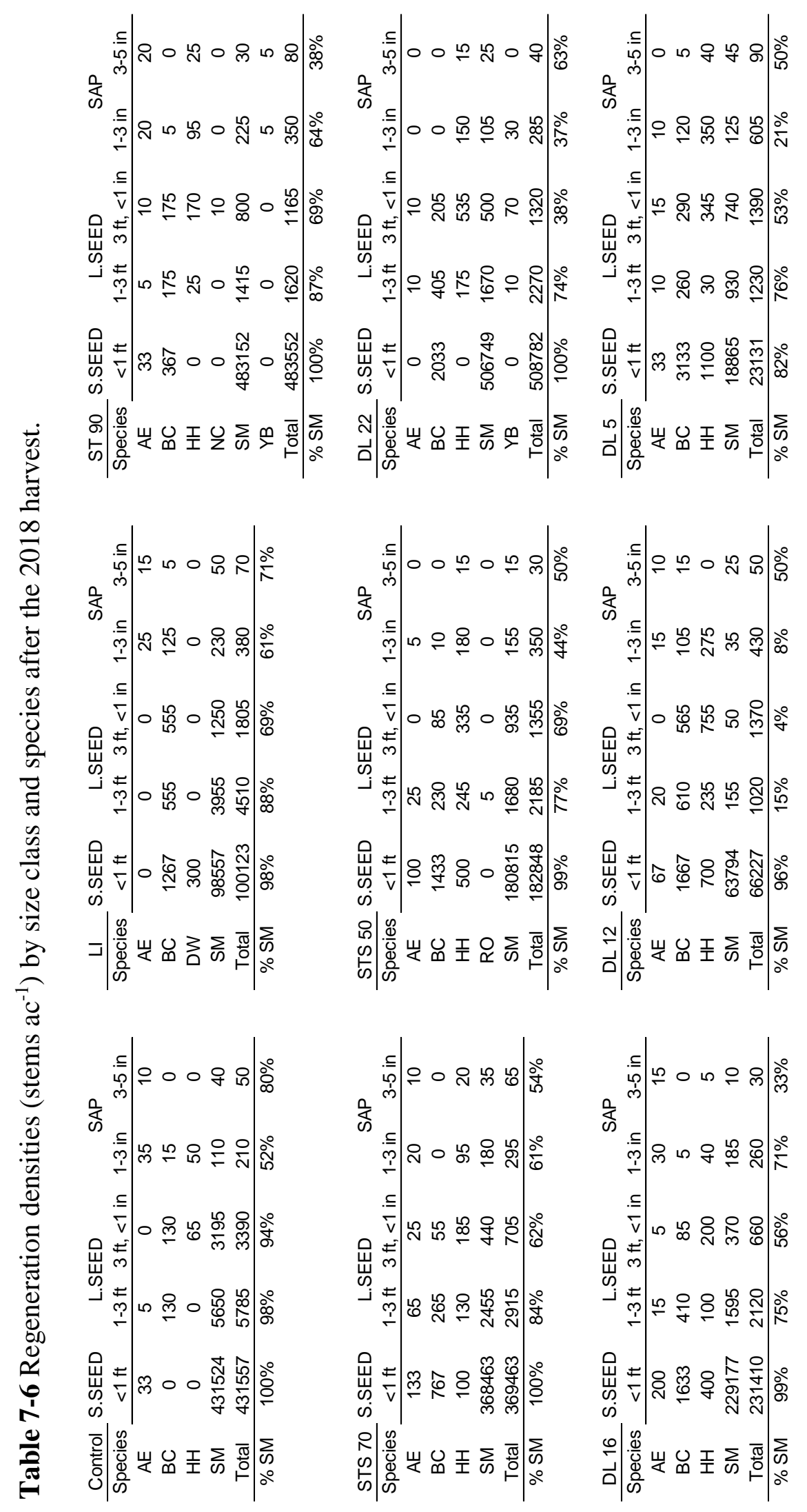


Table 7-7 Summary information for treatments in the Cutting Methods Study, Alberta, Michigan. Information adapted from Draper (2021)

\begin{tabular}{|c|c|c|c|}
\hline Treatment & Description & $\begin{array}{c}\text { Treatment } \\
\text { Unit Area (ac) }\end{array}$ & Entry Yeara \\
\hline $\mathrm{DL} 22^{\mathrm{c}}$ & $\begin{array}{l}\text { Remove all trees above } 22 \text { in } \\
\text { dbh. No tending below the } \\
\text { limiting diameter. }\end{array}$ & 4.65 & $\begin{array}{c}1956,1968,1998, \\
2008,2018\end{array}$ \\
\hline DL $16^{c}$ & $\begin{array}{l}\text { Remove all trees above } 16 \text { in } \\
\text { dbh. No tending below the } \\
\text { limiting diameter. }\end{array}$ & 3.6 & $\begin{array}{l}1956,1968,1978, \\
1988,1998,2008, \\
2018\end{array}$ \\
\hline $\mathrm{DL} 12^{\mathrm{c}}$ & $\begin{array}{l}\text { Remove all trees above } 12 \text { in } \\
\text { dbh. No tending below the } \\
\text { limiting diameter. }\end{array}$ & 4.91 & $\begin{array}{c}1957,1988,2008, \\
2018\end{array}$ \\
\hline DL 5 & $\begin{array}{l}\text { Remove all trees above } 5 \text { in } \\
\text { dbh. No tending below the } \\
\text { limiting diameter. }\end{array}$ & 4.65 & 1956, 1998 \\
\hline STS $90^{\mathrm{b}, \mathrm{c}}$ & $\begin{array}{l}\text { Single-tree selection to } 90 \mathrm{ft}^{2} \\
\mathrm{ac}^{-1} \text { with a limiting diameter of } \\
24 \mathrm{in} \text {. }\end{array}$ & 4.25 & $\begin{array}{c}1957,1968,1978, \\
1998,2008\end{array}$ \\
\hline STS 70 & $\begin{array}{l}\text { Single-tree selection to } 70 \mathrm{ft}^{2} \\
\mathrm{ac}^{-1} \text { with a limiting diameter of } \\
24 \mathrm{in} \text {. }\end{array}$ & 5.7 & $\begin{array}{c}1956,1968,1978, \\
1988,1998,2008, \\
2018\end{array}$ \\
\hline $\operatorname{STS} 50^{\mathrm{b}, \mathrm{c}}$ & $\begin{array}{l}\text { Single-tree selection to } 50 \mathrm{ft}^{2} \\
\mathrm{ac}^{-1} \text { with a limiting diameter of } \\
24 \mathrm{in} \text {. }\end{array}$ & 5.25 & $\begin{array}{c}1957,1968,1978, \\
1988,1998,2008, \\
2018\end{array}$ \\
\hline LI & $\begin{array}{l}\text { 'Light Improvement" } \\
\text { treatment to improve residual } \\
\text { stand quality. }\end{array}$ & 7.4 & $\begin{array}{l}1957,1968,1978, \\
1988,1998,2008, \\
2018\end{array}$ \\
\hline control & $\begin{array}{l}\text { Not harvested over study } \\
\text { period. }\end{array}$ & 14.4 & N/A \\
\hline
\end{tabular}

a Harvests after 1956-57 were completed in the fall/winter of stated year b Harvests between 1956-1988 used trees 10 in dbh and greater for the residual basal area. Starting with 1998, residual basal area was measured using trees 5 in dbh and greater

c Salvage harvest to remove dead and dying American elm in 1980 